\title{
RESPONSABILIDAD DEL SUPERIOR \\ JERÁRQUICO Y RESPONSABILIDAD \\ PENAL POR OMISIÓN DE MIEMBROS DE \\ LA FUERZA PÚBLICA EN COLOMBIA: \\ ¿CONVERGENCIA ENTRE EL DERECHO \\ PENAL NACIONAL E INTERNACIONAL?*
}

\section{COMMAND RESPONSIBILITY AND CRIMINAL LIABILITY BY OMISSION OF MEMBERS OF THE PUBLIC FORCE IN COLOMBIA: CONVERGENCE BETWEEN NATIONAL AND INTERNATIONAL CRIMINAL LAW?}

\author{
Gustavo Emilio Cote-Barco** \\ Fecha de recepción: 28 de junio de 2016 \\ Fecha de aceptación: 11 de julio de 2016 \\ Disponibilidad en linea: 30 de julio de 2016
}

\section{PARA CITAR este ARTículo / To CITE THIS ARTICLE} Cote-Barco, Gustavo Emilio, Responsabilidad del superior jerárquico y responsabilidad penal por omisión de miembros de la fuerza pública en Colombia: ¿convergencia entre el derecho penal nacional e internacional?, 28 International Law, Revista Colombiana de Derecho Internacional, 49-112 (2016). http://dx.doi.org/10.11144/ Javeriana.il 14-28.rsjr

doi:10.11144/Javeriana.i114-28.rsjr

* Artículo de reflexión escrito durante el Doctorado en Derecho en la Georg-August-Universität de la ciudad de Göttingen, Alemania (GAU). El autor agradece a María Victoria Cabrera (doctoranda de la GAU) por sus comentarios a la versión preliminar y a los editores de International Law por la revisión de estilo y por haber permitido actualizar este trabajo después de haber sido presentado. Las direcciones electrónicas en la bibliografía y en la lista de decisiones judiciales y de normas citadas han sido incluidas por los editores de la revista.

** Estudiante del doctorado en Derecho e investigador del Centro de Estudios de Derecho Penal y Procesal Penal Latinoamericano de la GAU; profesor asistente de la Facultad de Ciencias Jurídicas de la Pontificia Universidad Javeriana de Bogotá (PUJ). Magister Legum (LLM) de la GAU; magíster en Derecho con énfasis en ciencias penales y criminológicas de la Universidad Externado de Colombia; especialista en Instituciones Jurídico-Penales de la Universidad Nacional de Colombia; abogado de la PUJ. Contacto: gcote@javeriana.edu.co 


\section{RESUMEN}

Desde el 4 de septiembre de 2012, cuando oficialmente inició el proceso de paz entre el gobierno colombiano y las Fuerzas Armadas Revolucionarias de Colombia, se ha hecho referencia en varios contextos a la doctrina de responsabilidad del superior jerárquico. Sin embargo, es importante diferenciar, por un lado, el ámbito de aplicación de esta doctrina tal como ha sido desarrollada en el Derecho Penal Internacional y, por otro lado, el régimen de responsabilidad por omisión según el Código Penal colombiano (CPC). El presente trabajo explora las formas de responsabilidad penal y las hipótesis fácticas que la doctrina de responsabilidad del superior abarca. También analiza algunas decisiones judiciales colombianas sobre la responsabilidad penal por omisión de miembros de la Fuerza Pública (en especial con relación al artículo $25 \mathrm{CPC}$ ) y discute algunos problemas dogmáticos que se han presentado en estos casos. Al respecto, sostiene que la doctrina de responsabilidad del superior y el artículo 25 CPC solo coinciden parcialmente y que en el ordenamiento jurídico interno es necesario recurrir también a tipos penales de omisión propia para cubrir algunas hipótesis que sí podrían ser cubiertas por la doctrina de responsabilidad del superior como ha sido definida, por ejemplo, en el Estatuto de Roma. Finalmente, se llama la atención sobre la importancia de no confundir los dos ámbitos de responsabilidad para no reproducir en el sistema jurídico colombiano algunos de los problemas que se han presentado en el contexto del Derecho Internacional.

Palabras clave: Superior jerárquico; comisión por omisión; posición de garante; Estatuto de Roma; Código Penal colombiano; Jurisdicción Especial para la Paz 


\section{ABSTRACT}

Since 4 September 2012, the official beginning of the peace process between the Colombian government and the FARC (Revolutionary Armed Forces of Colombia), there has been much discussion about the possible application of the doctrine of command responsibility in the prosecution of international crimes by national courts. However, the scope of this doctrine, as developed in international criminal law, should be differentiated from the notion of criminal liability by omission under the Colombian Criminal Code (CCC). This paper explores the forms of criminal liability and the factual hypothesis that the doctrine of command responsibility covers. It also examines some decisions of the Colombian courts in which the notion of criminal liability by omission of armed force members is applied (especially with regard to the general provision contained in article 25 CCC), indicating some legal problems that have arisen in this regard. This paper seeks to demonstrate that the doctrine of command responsibility and the general provision of article 25 CCC, though closely related, are not the same. In doing so, it claims that Colombian courts should apply norms of the criminal code's special part to cover some factual hypothesis which are not covered by article 25 CCC, but still fall within the scope of the doctrine of command responsibility as defined, for example, in the Rome Statute. Finally, it maintains that the confusion of these two regimes of criminal liability could lead us to transfer into the Colombian legal system some of the problems faced in the application of international criminal law.

Keywords: Command responsibility; commission by omission; guarantor's duties; Rome Statute; Colombian Criminal Code; Special Jurisdiction for Peace

\section{SUMARIO}

INTRODUCCIÓN.- I. REFERENCIAS A LA DOCTRINA DE RESPONSABILIDAD DEL SUPERIOR JERÁRQUICO DURANTE EL PROCESO DE PAZ EN COLOMBIA: ESFUERZOS PARA DELIMITAR LA RESPONSABILIDAD PENAL DE MIEMBROS DE LA FuERZA PÚBLICA.- II. LA DOCTRINA DE RESPONSABILIDAD DEL SUPERIOR JERÁRQUICO SEGÚN EL artículo 28 del Estatuto de la Corte Penal Internacional: contornos Y REQUISITOS.- III. RESPONSABILIDAD PENAL POR OMISIÓN DE MIEMBROS DE LA Fuerza Pública en Colombia: desarrollo jurisprudencial del artículo 25 del Código Penal colombiano.- IV. La doctrina de responsabilidad DEL SUPERIOR JERÁRQUICO Y LA RESPONSABILIDAD PENAL POR OMISIÓN EN EL Código Penal colombiano: puntos de encuentro y divergencias.- V. OBSERVACIONES FINALES: EN ESPECIAL CON RELACIÓN A LA RESPONSABILIDAD DEL SUPERIOR JERÁRQUICO Y LA JURISDICCIÓN ESPECIAL PARA LA PAZ.- BIBLIOGRAFÍA. 
INTRODUCCIÓN

En los últimos años, especialmente con ocasión del proceso de paz que adelantó el gobierno colombiano con el grupo guerrillero Fuerzas Armadas Revolucionarias de Colombia (FARC), se ha hecho referencia en diferentes escenarios a la responsabilidad penal de mandos militares por violaciones de derechos humanos (DDHH) e infracciones graves al Derecho Internacional Humanitario (DIH). En este contexto, una preocupación especial fue (y sigue siendo) la responsabilidad penal a título de omisión de miembros de la Fuerza Pública y la forma como estos casos serán tratados en la Jurisdicción Especial para la Paz (JEP) que se deberá crear como resultado de los acuerdos de La Habana (Cuba). Así pues, se ha aludido, en ocasiones de forma implícita, a la denominada "doctrina de responsabilidad por el mando" o "doctrina de responsabilidad del superior jerárquico" (DRSJ; en inglés, command responsibility), la cual constituye una forma de imputación de responsabilidad penal que ha sido desarrollada en el Derecho Internacional y que, dado el caso, podría ser tenida en cuenta en estos procesos penales. Sin embargo, con el fin de que las decisiones judiciales que se tomen con relación a este tema estén fundamentadas en debida forma, se debe diferenciar, por un lado, el ámbito de aplicación de esta doctrina de acuerdo con el Derecho Penal Internacional (DPI) y, por otro lado, el régimen de responsabilidad por omisión que corresponde a casos de este tipo según el Código Penal colombiano (CPC). En otras palabras: a pesar de que el DPI constituye un punto de referencia obligado para la persecución penal de crímenes internacionales por parte de jueces nacionales, las reglas que pertenecen a cada uno de estos dos regímenes de responsabilidad no se deben confundir. Solo así es posible identificar vacíos en la legislación interna y, de ser posible, recurrir de manera consistente al Derecho Internacional para tratar de complementar las disposiciones nacionales.

Por esta razón, en el presente trabajo se abordará la DRSJ, con el fin de precisar cuál es la forma de responsabilidad penal a 
la que esta hace referencia, cuáles son sus requisitos y qué tipos de casos están cubiertos por esta figura. De la misma manera, se indagará sobre cuál ha sido la manera en la que la jurisprudencia colombiana se ha aproximado al problema de la responsabilidad por omisión de miembros de la Fuerza Pública, sobre todo por medio del artículo 25 CPC y la figura de la posición de garante. Con esto se pretende identificar hasta qué punto la DRSJ y el artículo 25 CPC coinciden. Es decir, se trata de establecer hasta qué punto los casos que se pueden subsumir en la DRSJ pueden serlo también en el artículo 25 CPC (claro está, teniendo en cuenta la jurisprudencia colombiana sobre esta norma) y si el artículo 25 tiene un campo de aplicación más estrecho o más amplio que el de la DRSJ. Con este análisis, se quieren identificar posibles "vacíos" en la legislación penal colombiana, y advertir sobre algunos problemas dogmáticos que se pueden presentar (y que, de hecho, se han presentado) en el tratamiento de la responsabilidad penal por omisión cuando se trata de hechos relacionados con el conflicto armado.

Para esto, se procederá de la siguiente manera: (i) en primer lugar, con el fin de ilustrar la relevancia del tema y plantear algunos interrogantes preliminares, se mostrarán tres referencias concretas a la DRSJ que se hicieron en Colombia desde el inicio del proceso de paz; (ii) posteriormente, se procederá a definir los aspectos más relevantes de esta doctrina, lo cual se hará con base en el artículo 28 del Estatuto de la Corte Penal Internacional (ECPI); (iii) en tercer lugar, se hará referencia brevemente al artículo 25 CPC y a la forma como la jurisprudencia colombiana ha interpretado esta norma en casos de responsabilidad penal por omisión de miembros de la Fuerza Pública; (iv) después se contrastarán los ámbitos de aplicación de la DRSJ como ha sido desarrollada en el DPI y del artículo 25 CPC, para esclarecer posibles puntos de encuentro y divergencias; $y$, para terminar, (v) se plantearán algunas reflexiones generales especialmente con relación a la DRSJ y la JEP. 
I. REFERENCIAS A LA DOCTRINA DE RESPONSABILIDAD DEL SUPERIOR JERÁRQUICO DURANTE EL PROCESO DE PAZ EN COLOMBIA: ESFUERZOS PARA DELIMITAR LA RESPONSABILIDAD PENAL DE MIEMBROS DE LA FUERZA PÚBLICA

Desde el comienzo del proceso de paz que adelantó el gobierno colombiano con las FARC se ha discutido intensamente sobre la forma como se deben tratar los crímenes cometidos por las partes enfrentadas y que implican violaciones de DDHH o infracciones graves al DIH. En este contexto, un aspecto que ha generado especial preocupación es el de la responsabilidad penal por omisión de los mandos militares, sobre todo cuando se trata de miembros de la Fuerza Pública colombiana. De hecho, en varias ocasiones se ha hecho referencia a la DRSJ, bajo el entendido de que el Derecho Internacional contiene estándares mínimos que se deben observar en el ámbito interno en este tipo de situaciones. Es posible mencionar entonces los siguientes tres ejemplos en los que esta doctrina ha sido traída a colación: (i) la primera decisión de la Corte Constitucional colombiana sobre el Marco Jurídico para la Paz (MJP); (ii) la reforma al fuero penal militar que discutió el Congreso de la República entre 2012 y 2013 y la reforma a la jurisdicción penal militar que se aprobó en 2015; y, (iii) el proceso de paz que llevó al acuerdo firmado (finalmente) el 24 de noviembre de 2016 entre el gobierno colombiano y las FARC como resultado de las negociaciones de La Habana.

En la sentencia C-579-13', en la que se declaró la exequibilidad del inciso cuarto del artículo 1 del Acto Legislativo 1 de 2012 o $\mathrm{MJP}^{2}$, mediante el cual se incorporó a la Constitución Política colombiana el artículo transitorio 66, la Corte Constitucional se refirió a la DRSJ al tratar de definir la expresión "máximos responsables". Con esta disposición se autorizó al Congreso para

1 Corte Constitucional, Sentencia C-579-13, 28 de agosto de 2013, magistrado ponente Jorge Ignacio Pretelt-Chaljub.

2 Colombia, Acto Legislativo 1 de 2012, por medio del cual se establecen instrumentos jurídicos de justicia transicional en el marco del artículo 22 de la Constitución Política y se dictan otras disposiciones, 48.058 Diario Oficial, 31 de julio de 2012. 
que mediante ley estatutaria estableciera criterios de selección de casos que le permitieran a la Fiscalía General de la Nación (FGN), en el contexto de mecanismos de justicia transicional, centrar sus esfuerzos en la investigación penal "de los máximos responsables de todos los delitos que adquieran la connotación de crímenes de lesa humanidad, genocidio, o crímenes de guerra cometidos de manera sistemática"3. Pues bien, la Corte afirmó en esta decisión: "el parámetro de máximo responsable es un criterio ascendente que permite incluir no solamente a quien haya tenido una intervención decisiva en el delito, sino también a otras personas en virtud de criterios como el de la responsabilidad del superior 'Command responsibility' [...]”" En consecuencia, según la Corte Constitucional, en cumplimiento del artículo transitorio 66, la DRSJ está llamada a darle contenido a la idea de "máximos responsables" y en este sentido, puede hacer las veces de criterio de selección para que la FGN centre sus esfuerzos en la investigación de los crímenes más graves. Es decir, de acuerdo con esta afirmación de la Corte Constitucional, los casos en los que se cumplen los requisitos de la DRSJ ostentan una gravedad tal que ameritan ser seleccionados para que se investiguen por medio de los mecanismos de justicia transicional de carácter penal que se establezcan con posterioridad a un acuerdo de paz. Así las cosas, esta doctrina debería ser tenida en cuenta tanto por el legislador colombiano en el momento de desarrollar el MJP como también por la FGN a la hora de seleccionar los casos más graves.

La DRSJ también fue mencionada en el proyecto de ley estatutaria 268 (Cámara) y 211 (Senado) de 2013, con el que se

3 Colombia, Constitución Política, versión corregida, 116 Gaceta Constitucional, 20 de julio de 1991, artículo transitorio 66, inciso cuarto. Disponible en: http://www.secretariasenado.gov. co/index.php/constitucion-politica

4 Corte Constitucional, nota al pie 1, apartado 8.2.3. Al respecto, Gustavo Emilio Cote-Barco \& Diego Fernando Tarapués-Sandino, El Marco Jurídico para la Paz y el análisis estricto de sustitución de la Constitución realizado en la Sentencia C-579 de 2013, en Justicia de Transición y Constitución, 197-271, p. 254-264 (Kai Ambos, coord., Temis, Bogotá, 2014).

5 Colombia, Proyecto de ley estatutaria 268 (Cámara), 211 de 2013 (Senado), por la cual se desarrollan los artículos 116 y 221 de la Constitución Política de Colombia y se dictan otras disposiciones, ponencia para primer debate en Comisiones Primeras Conjuntas, 350 Gaceta del Congreso, 22 de mayo de 2013. 
pretendía desarrollar el Acto Legislativo 2 de 2012, mediante el cual se reformaban los artículos 116, 152 y 221 de la Constitución Política y se realizaban algunas reformas relacionadas con el fuero penal militar ${ }^{6}$. Este proyecto de ley establecía en diferentes artículos tres "estructuras de imputación", con el fin de armonizar el Derecho Penal nacional con el Derecho Internacional (según se desprende del Título II bajo el cual se encontraban estas disposiciones). Así, el artículo 31 definía la posición de garante para miembros de la Fuerza Pública ${ }^{7}$, mientras que el artículo 32 regulaba la "responsabilidad del superior militar o policial por las conductas de los subordinados". Si bien más adelante se abordarán los requisitos de la DRSJ, por el momento es importante resaltar que el artículo 32 hacía referencia al "control efectivo" del superior sobre los autores del delito, lo cual constituye precisamente uno de los elementos de este tipo de responsabilidad según el DPI ${ }^{8}$. Además, en el parágrafo $1^{\circ}$ del artículo 32 se aclaraba que, en ningún caso el superior militar o policial podría ser declarado responsable "por la sola posición formal de jerarquía sobre los autores del delito". Este

6 Entre otras cosas el Acto Legislativo 2 de 2012 (artículo 3) establecía que las infracciones al DIH cometidas por miembros de la Fuerza Pública en servicio activo, y en relación con el mismo servicio, serían conocidas exclusivamente por las cortes marciales o tribunales militares o policiales. Colombia, Acto Legislativo 2 de 2012, por el cual se reforman los artículos 116, 152 y 221 de la Constitución Política de Colombia, 48.657 Diario Oficial, 28 de diciembre de 2012.

7 El artículo 31 de este proyecto de ley estatutaria disponía: "El miembro de la Fuerza Pública que en razón de su competencia funcional y teniendo el control efectivo, tenga el deber jurídico de evitar un resultado previsto en la ley penal como punible y no lo hiciere, disponiendo de los recursos y medios, siempre que las circunstancias fácticas se lo permitan, quedará sujeto a la pena prevista en la respectiva norma penal.

A tal efecto, se requiere que tenga a su cargo la protección real y efectiva del bien jurídico protegido o la vigilancia de una determinada fuente de riesgo, conforme a la Constitución, la ley o los reglamentos".

8 Según el artículo 32 del proyecto de ley estatutaria: "El superior militar o policial será responsable por las conductas de sus subordinados cuando se reúnan las siguientes condiciones concurrentes: a) La comisión de un delito ocurra en desarrollo de las hostilidades; b) El superior militar o policial tenga el mando y control efectivo sobre los autores del delito; c) El superior militar o policial hubiere sabido, o en razón de las circunstancias del momento hubiera debido saber que se cometió o se iba a cometer un delito; d) El superior militar o policial omita la prevención del delito o la denuncia del mismo a las autoridades competentes, teniendo la posibilidad fáctica de prevenirlo o denunciarlo, según sea el caso.

La responsabilidad penal del superior obedecerá a la naturaleza de la relación jerárquica, la cual será valorada en cada caso atendiendo las especificidades de las operaciones militares y policiales, y la capacidad efectiva de ejercer el mando". 
proyecto de ley no continuó su trámite debido a que el Acto Legislativo 2 de 2012 fue declarado inexequible en su totalidad por vicios de forma $\mathrm{m}^{9} \mathrm{y}$, en consecuencia, no fue posible realizar el control de constitucionalidad previo que debe adelantar la Corte Constitucional cuando se trata de leyes estatutarias. De hecho, la Corte Constitucional se declaró inhibida "por carencia actual de objeto" para pronunciarse de fondo sobre este proyecto $^{10}$. En todo caso, por medio del artículo 99 de la Ley 1765 de $2015^{11}$, mediante la cual se reestructuró la justicia penal militar, se modificó el artículo 27 de la Ley 1407 de 2010 (Código Penal Militar, en adelante CPM), norma que regula la responsabilidad por omisión de miembros de la Fuerza Pública por actos cometidos en relación con el servicio. De esta forma, la disposición sobre posición de garante que se encontraba en el artículo 31 del proyecto de ley estatutaria aquí mencionado se llevó al CPM. Sin embargo, no ocurrió lo mismo con la disposición que en el proyecto de ley estatutaria hacía referencia expresa a la DRSJ, lo cual tiene sentido, ya que según lo dispone el artículo 3 CPM (en la misma dirección que la jurisprudencia constitucional al respecto) $)^{12}$, la justicia castrense no puede conocer hechos que constituyan crímenes internacionales, entre ellos infracciones graves al $\mathrm{DIH}^{13}$.

9 Corte Constitucional, Sentencia C-740-13, 23 de octubre de 2013, magistrado ponente Nilson Pinilla-Pinilla.

10 Corte Constitucional, Sentencia C-388-14, 25 de junio de 2014, magistrado ponente Luis Guillermo Guerrero-Pérez. Con posterioridad a este intento de reforma se expidió el Acto Legislativo 1 de 2015, mediante el cual se reformó el artículo 221 de la Constitución Política. El sentido y la pertinencia de esta reforma han sido cuestionados, dado que al parecer este Acto Legislativo se limitó a reiterar la aplicabilidad del DIH en "la investigación y juzgamiento de las conductas punibles de los miembros de la Fuerza Pública, en relación con un conflicto armado o un enfrentamiento que reúna las condiciones objetivas del Derecho Internacional Humanitario". Al respecto la Corte Constitucional aclaró que esta disposición no podía entenderse en el sentido de excluir en este tipo de casos otras fuentes del Derecho como el Derecho Internacional de los Derechos Humanos. Corte Constitucional, Sentencia C-084-16, 24 de febrero de 2016, magistrado ponente Luis Ernesto Vargas-Silva, parágrafo 110.

11 Colombia, Ley 1765 de 2015, por la cual se reestructura la Justicia Penal Militar y Policial [...], 49.582 Diario Oficial, 23 de julio de 2015.

12 Corte Constitucional, Sentencia C-358-97, 5 de agosto de 1997, magistrado ponente Eduardo Cifuentes-Muñoz. Corte Constitucional, Sentencia C-878-00, 12 de julio de 2000, magistrado ponente Alfredo Beltrán-Sierra. Corte Constitucional, Sentencia SU1184-01, 13 de noviembre de 2001, magistrado ponente Eduardo Montealegre-Lynett.

13 Este era justamente uno de los aspectos que se pretendían cambiar con el Acto Legislativo 02 de 2012. Precisamente, por esta razón el proyecto de ley estatutaria que desarrollaba dicha 
Finalmente, la DRSJ fue un tema sobre el que se discutió varias veces durante el proceso de paz que se llevó a cabo en Cuba entre el gobierno colombiano y las FARC. En el borrador conjunto de acuerdo sobre víctimas del conflicto ${ }^{14}$ se trajo a colación la DRSJ. Este documento fue publicado el 15 de diciembre de 2015 y en él aparece la DRSJ en tres ocasiones. En el acápite en el que se explica el componente de justicia (5.1.2.) y se define la JEP, el punto 44 (bajo el título II. Contenidos, alcances y límites de la concesión de amnistías e indultos así como de otros tratamientos especiales) dispone que, respecto a los agentes del Estado, se debe establecer un "tratamiento especial, simultáneo, equilibrado y equitativo basado en el Derecho Internacional Humanitario", y a renglón seguido se mencionan de manera general algunos de los requisitos de la DRSJ. Según el punto 44 del borrador de acuerdo sobre víctimas: "En ningún caso la responsabilidad del mando podrá fundarse exclusivamente en el rango, la jerarquía o el ámbito de jurisdicción. La responsabilidad de los miembros de la fuerza pública por los actos de sus subordinados deberá fundarse en el control efectivo de la respectiva conducta, en el conocimiento basado en la información a su disposición antes, durante y después de la realización de la respectiva conducta, así como en los medios a su alcance para prevenir, y de haber ocurrido, promover las investigaciones procedentes". Es importante llamar la atención sobre la primera frase de este punto ("En ningún caso la responsabilidad del mando podrá fundarse exclusivamente en el rango, la jerarquía o el ámbito de jurisdicción"), ya que ella reproduce la misma idea del parágrafo $1^{\circ}$ del artículo 32 del proyecto de ley estatutaria que se mencionó anteriormente. Por otro lado, más adelante en el punto 59 del borrador de acuerdo sobre víctimas (bajo el título III. Procedimiento, órganos y sanciones del componente de

reforma constitucional incluía de forma expresa una disposición sobre la responsabilidad del superior militar, lo cual se dejó de lado una vez este intento de reforma fracasó.

14 Acuerdo sobre las Víctimas del Conflicto (borrador conjunto), "Sistema Integral de Verdad, Justicia, Reparación y No Repetición", incluyendo la Jurisdicción Especial para la Paz; y Compromiso sobre Derechos Humanos, Comunicado Conjunto 64, La Habana, 15 de diciembre de 2015. 
justicia del SIVJRNR) ${ }^{15}$ se encuentra nuevamente más o menos la misma disposición, pero esta vez con relación a los mandos de las FARC. Además, bajo este mismo título en el punto 48 (i) se prevé que los máximos responsables, "por responsabilidad de mando", deberán ser identificados individualmente por "la Sala de reconocimiento de verdad y responsabilidad y de determinación de los hechos y conductas" al recibir las declaraciones de reconocimiento de verdad y de responsabilidad, tanto individuales como colectivas. Estos puntos reiteran la importancia de esta doctrina para determinar quiénes fueron los máximos responsables de los crímenes relevantes en el contexto de la JEP. Asimismo, la referencia que se hace en el punto 48 (i) permite afirmar que siempre que la comisión de un crimen se pueda explicar por la falta de control por parte del superior jerárquico, este debe ser identificado. Pero estas referencias también permiten plantear algunos interrogantes, por ejemplo: ¿la referencia hecha en el punto 44 con relación a los agentes del Estado sugiere que la aplicación de la DRSJ constituye alguna especie de "tratamiento especial"? ¿Era necesario establecer en un acuerdo sobre mecanismos de justicia transicional que la DRSJ, como está definida en el acuerdo, debe ser aplicada por igual a miembros de la Fuerza Pública y de la guerrilla?

Las referencias a la DRSJ que se hicieron en los puntos 44 (con relación a agentes del Estado) y 59 (con relación a integrantes de las FARC) del borrador de acuerdo sobre víctimas fueron reiteradas sin modificaciones en el acuerdo "final" firmado el 24 de agosto de $2016^{16}$. Sin embargo, en la segunda versión del acuerdo final, la cual apareció inicialmente con fecha del 12 de noviembre del mismo año, se agregó un nuevo párrafo a estos dos puntos, mediante el cual se precisó que la expresión "control efectivo sobre la respectiva conducta" (párrafo primero) hace alusión a "la posibilidad real que el superior tenía de haber ejercido un control apropiado sobre sus subalternos, en relación con

15 Sistema Integral de Verdad, Justicia, Reparación y No Repetición que se diseñó en este acuerdo.

16 Acuerdo final para la terminación del conflicto y la construcción de una paz estable y duradera, 28 de agosto de 2016, p. 137, 147. 
la ejecución de la conducta delictiva”, para lo cual se mencionó como punto de referencia el artículo $28 \mathrm{ECPI}^{17}$. Esta referencia explícita al artículo 28 del ECPI se eliminó del punto 59 mediante una "fe de erratas" publicada en un comunicado conjunto el 24 de noviembre de 2016 y se cambió por una referencia genérica al Derecho Internacional ${ }^{18}$. Curiosamente, con relación a los agentes del Estado no se hizo la misma modificación. Sin embargo, en la página web de la Mesa de Conversaciones apareció una nueva versión del acuerdo final, esta vez con fecha del 24 de noviembre, en la que el párrafo que se había incluido en la versión del acuerdo del 12 de noviembre y que aclara el significado de la expresión "control efectivo sobre la respectiva conducta" se retiró del punto 44, quedando dicha disposición como inicialmente se había redactado en el borrador conjunto del 15 de diciembre de

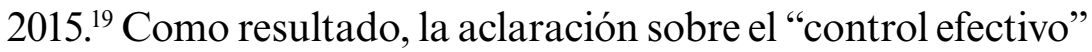
aparece solo en el punto 59, el cual se refiere a los integrantes de las FARC, pero no en el 44 al hablarse de la responsabilidad de los superiores cuando se trata de agentes del Estado.

Es claro, entonces, que desde hace algunos años ha habido un interés constante en delimitar la responsabilidad penal por omisión de los miembros de la Fuerza Pública colombiana y que para esto se ha acudido a la DRSJ o al menos a algunos de sus elementos. Por esto, al margen de los interrogantes que pueden surgir de estas propuestas e incluso del acuerdo sobre víctimas, lo cierto es que estas referencias permiten afirmar que la DRSJ posiblemente ocupará un lugar central en los debates sobre responsabilidad penal por violaciones a los DDHH y graves infracciones al DIH, que tendrán lugar en los procesos que se surtirán ante la JEP. De ahí que resulte fundamental entender el alcance de esta figura y el lugar que puede tener en el ordenamiento jurídico colombiano, así como su relación con el Código Penal.

17 Acuerdo final para la terminación del conflicto y la construcción de una paz estable y duradera, 12 de noviembre de 2016, p. 151-152, 164.

18 Comunicado Conjunto \# 7, Bogotá, Colombia, 24 de noviembre de 2016, p. 2 (numeral 7).

19 Acuerdo final para la terminación del conflicto y la construcción de una paz estable y duradera, 24 de noviembre de 2016, p. 152. 


\section{LA DOCTRINA DE RESPONSABILIDAD DEL SUPERIOR JERÁRQUICO SEGÚN EL ARTÍCULO 28 DEL ESTATUTO DE LA Corte Penal Internacional: CONTORNOS Y REQUisitos}

A continuación, se hará una breve referencia a la forma como la DRSJ ha sido definida en el DPI, en especial en el artículo 28 ECPI. Se debe advertir que en las siguientes consideraciones no se hará un estudio detallado de la evolución de esta figura ni se profundizará en cada uno de sus elementos, ya que esto excede el propósito de este trabajo. Se trata de una explicación general, a partir de la cual se resaltarán algunos aspectos que se consideran relevantes (varios de ellos aún controversiales y discutidos en la jurisprudencia y en la literatura especializada), con el fin de reflexionar posteriormente sobre la responsabilidad penal por omisión de miembros de la Fuerza Pública y su tratamiento en el Derecho Penal colombiano.

La DRSJ fue desarrollada inicialmente en los procesos que tuvieron lugar con posterioridad a la Segunda Guerra Mundial, sobre todo en el famoso proceso contra el General japonés Tomoyuki Yamashita, cuya condena a muerte por ahorcamiento en decisión de primera instancia fue proferida el 7 de diciembre de 1945 en Manila (Filipinas) por una comisión militar de Estados Unidos ${ }^{20}$, y en los procesos contra Wilhelm List y otros (Hostage Case, Hostage Trial o Geisel-Prozess) ${ }^{21}$ y Wilhelm von Leeb y otros (High Command Trial o OKW-Prozess) ${ }^{22}$, los cuales tuvieron lugar en Alemania ante tribunales militares de la zona de ocupación estadounidense conforme a la Ley 10 del Consejo

20 La Corte Suprema de Estados Unidos de América se pronunció al respecto el 4 de febrero de 1946. Sentenciado a muerte, fue ahorcado - muerte deshonrosa para un militar- el 23 de febrero de 1946. United Nations War Crimes Commission, Law Reports of Trials of War Criminals, Volume IV, 33-49 (United Nations War Crimes Commission, London, 1948).

21 Este proceso tuvo lugar entre el 8 de julio de 1947 y el 19 de febrero de 1948 en la ciudad de Núremberg ante un tribunal penal militar estadounidense. United Nations War Crimes Commission, Law Reports of Trials of War Criminals, Volume VIII, 34-92 (United Nations War Crimes Commission, London, 1949).

22 Este proceso se llevó a cabo del 30 de diciembre de 1947 al 28 de octubre de 1948 también ante un tribunal penal militar estadounidense en la ciudad de Núremberg. United Nations War Crimes Commission, Law Reports of Trials of War Criminals, Volume XII (United Nations War Crimes Commission, London, 1949). 
de Control conformado por los países aliados ${ }^{23}$. Sin embargo, esta doctrina fue "codificada" por primera vez en 1977 en el Protocolo Adicional I (PA I) a los Convenios de Ginebra (CG) ${ }^{24}$. En el artículo 87.1 PA I están previstos los deberes de los superiores, concretamente los deberes de prevenir, reprimir y reportar violaciones a los CG y al Protocolo mismo ${ }^{25}$, y en el artículo 86 se establece que el hecho de que las infracciones a los CG o al PA I hayan sido cometidas por los subordinados no debe eximir de responsabilidad penal o disciplinaria a los superiores, cuando estos han incumplido estos deberes ${ }^{26}$. Más aún, actualmente se ha aceptado que la DRSJ tiene carácter consuetudinario y que se debe aplicar tanto en conflictos armados internacionales como no internacionales ${ }^{27}$. De hecho, así fue reconocido, por ejemplo,

23 Allied Control Council, Law No. 10, Punishment of Persons Guilty of War Crimes, Crimes against Peace and against Humanity, Berlin, 20 December 1945.

24 La idea central de la DRSJ se puede inferir también del artículo 1 de las regulaciones de La Haya de 1907 y está en los artículos 4A(2) y 39 del CG III y 99 del CG IV. Claude Pilloud, Jean de Preux, Bruno Zimmermann, Philippe Eberlin, Hans-Peter Gasser \& Claude Wenger, Protocol I, en Commentary on the Additional Protocols of 8 June 1977 to the Geneva Conventions of 12 August 1949, 1011 (Jean Pictet, Chairman, Martinus Nijhoff Publishers, Geneva, 1987).

25 Además, según el artículo 87.2 PA I, los superiores deben asegurar que el personal bajo su mando conozca las obligaciones que tienen de acuerdo con las Convenciones y el Protocolo mismo, y tomar las medidas necesarias para prevenir violaciones a las Convenciones o al Protocolo o, de ser el caso, para iniciar las acciones disciplinarias o penales que sean pertinentes.

26 De acuerdo con Thomas Weigend, la responsabilidad de los superiores se fundamenta en su poder de impartir órdenes sobre personas armadas, las cuales, por regla general, se deben cumplir sin cuestionamientos. Este poder supone la expectativa de que las acciones de los subordinados serán controladas por el superior. Se puede afirmar entonces que el superior jerárquico tiene bajo su control una especial fuente de riesgo para los bienes jurídicos ajenos. Ver Thomas Weigend, Bemerkungen zur Vorgesetztenverantwortlichkeit im Völkerstrafrecht, 116 Zeitschrift für die gesamte Strafrechtswissenschaft, 4, 999-1027, p. 1004-1012 (2004). Sin embargo, se debe añadir que los subordinados también tienen la expectativa de que su superior cumplirá sus deberes de forma adecuada. Esta expectativa —o confianza - hace que el superior esté en una posición privilegiada y que en consecuencia deba responder por el incumplimiento de sus deberes. De hecho, el superior también debe velar por el bienestar de sus subordinados y evitar que ellos incurran en riesgos (físicos o jurídicos) injustificados. En otras palabras, para que la relación jerárquica entre el superior y el subordinado sea efectiva y la línea de mando en las estructuras militares pueda operar, se requiere que el superior ejerza debidamente sus obligaciones y que sea posible confiar en que así será. En este sentido, se puede ver la explicación de Kevin Riordan, Command Responsibility, en UN Audiovisual Library of International Law (14 February 2012). Disponible en: http://webtv.un.org/news-features/audiovisual-library-of-international-law-avl/ watch/kevin-riordan-on-command-responsibility/2623243067001 (última fecha de acceso: 22 de julio de 2016). Ver al respecto Robert Cryer, Håkan Friman, Darryl Robinson \& Elizabeth Wilmshurst, An Introduction to International Criminal Law and Procedure, 384 ( $3^{\mathrm{a}}$ ed., Cambridge University Press, Cambridge, 2014). Darryl Robinson, How Command Responsibility got so Complicated: A Culpability Contradiction, its Obfuscation, and a Simple Solution, 13 Melbourne Journal of International Law, 1-58, p. 11 (2012).

27 Jean-Marie Henckaerts \& Louise Doswald-Beck, Customary International Law, Volume I: 
por el Tribunal Penal Internacional para la ex Yugoslavia (TPIY $\mathrm{o}$, por sus siglas en inglés, ICTY ${ }^{28}$ y mediante su inclusión en los estatutos de otros tribunales penales internacionales adoptados para juzgar crímenes atroces cometidos en este tipo de conflictos, como por ejemplo en el Estatuto del Tribunal Penal Internacional para Ruanda (TPIR o, por sus siglas en inglés, ICTR) ${ }^{29} \mathrm{e}$ incluso en el Estatuto del Tribunal Penal Especial para Sierra Leona (TPESL) ${ }^{30}$. Sin embargo, la regulación más detallada se encuentra sin lugar a dudas en el artículo 28 del ECPI. En términos generales, es posible afirmar que la DRSJ supone los siguientes cinco elementos: (i) la condición de superior de la persona en cuestión ${ }^{31}$; (ii) el control efectivo del superior sobre el subordinado; (iii) el nexo de "causalidad" entre la omisión del superior y los crímenes efectivamente cometidos (aunque sea en grado de tentativa); (iv) el elemento subjetivo o mens rea en los términos definidos, por ejemplo, en el artículo 28 ECPI; y (v) el no haber adoptado todas las medidas necesarias y razonables para prevenir o reprimir la comisión del crimen o ponerlo en conocimiento de las autoridades competentes ${ }^{32}$. En este acápite

Rules, 559-560 (Cambridge University Press, Cambridge, 2005). Otto Triffterer \& Roberta Arnold, Article 28. Responsibility of Commanders and Other Superiors, en The Rome Statute of the International Criminal Court. A Commentary, 1056-1106, p. 1105-1106 (3ª ed., Otto Triffterer \& Kai Ambos, ed., C. H. Beck, Hart, Nomos, München, 2016).

28 ICTY, Prosecutorv. Enver Hadžihasanović, Mehmed Alagić and Amir Kubura (IT-01-47-AR72), Appeals Chamber, Decision on Interlocutory Appeal Challenging Jurisdiction in Relation to Command Responsibility, 16 July 2003, para. 11 ss.

29 Ver artículo 6.3 del Estatuto del TPIR. Al respecto: ICTR, Prosecutor v. Jean-Paul Akayesu (ICTR-96-4-T), Trial Chamber, Judgement, 2 September 1998, para. 486 ss.

30 Artículo 6.3 del Estatuto del TPESL. Con relación a la DRSJ en la jurisprudencia del TPESL, Denise Fuchs-Kaninski, Der Beitrag des Sondergerichtshofs für Sierra Leone zum Völkerstrafrecht, 174-189 (Optimus Verlag, Göttingen, 2015). Con relación a la DRSJ en las Cámaras Extraordinarias de Camboya, Russell Hopkins, The Case 002/01 Trial Judgment: A Stepping Stone from Nuremberg to the Present?, en The Extraordinary Chambers in the Courts of Cambodia. Assessing their Contribution to International Criminal Law, 181-201, p. 191-192 (Simon M. Meisenberg \& Ignaz Stegmiller, ed., Springer, Berlin, Heidelberg, 2016).

31 La posición de superior puede ser de jure o de facto. Al respecto, Otto Triffterer \& Roberta Arnold, nota al pie 27, p. 1091-1092. Kai Ambos, Treatise on International Criminal Law, Volume I, 208-210 (Oxford University Press, Oxford, 2014). Robert Cryer y otros, nota al pie 26, p. 386-388. Gerhard Werle, Völkerstrafrecht, 249-252 (3a ed., Mohr Siebeck, Tübingen, 2012). Ilias Bantekas, International Criminal Law, 82-86 (4 ed., Hart Publishing, Oxford, Portland, 2010).

32 Sobre el tipo de medidas (necesarias y razonables), Otto Triffterer \& Roberta Arnold, nota al pie 27, p. 1083. Kai Ambos, nota al pie 31, p. 217-220. Robert Cryer y otros, nota al pie 26, p. 390-392. Gerhard Werle, nota al pie 31, p. 254-257. 
se quiere llamar la atención especialmente sobre los elementos (ii), (iii) y (iv), para plantear finalmente la pregunta sobre el tipo de responsabilidad a la que se alude con esta doctrina. Sin embargo, antes de esto se harán algunas consideraciones con relación a los supuestos de hecho que la DRSJ abarca.

La primera distinción que se debe señalar tiene qué ver con los deberes de los superiores. Si bien el artículo 28 ECPI contempla una forma específica de responsabilidad por omisión para jefes $\mathrm{o}$ superiores de carácter militar y civil, esta responsabilidad no se fundamenta en el incumplimiento de un único deber. De hecho, de acuerdo con el artículo 28 ECPI, el cual sigue en este punto el artículo 87.1 PA I, tanto los superiores de carácter militar como civil tienen tres tipos de deberes: (i) adoptar "todas las medidas necesarias y razonables a su alcance para prevenir" la comisión de crímenes de competencia de la Corte Penal Internacional (CPI $\mathrm{o}$, por sus siglas en inglés, ICC) y, en caso de que ya se hayan cometido, (ii) reprimir su comisión o (iii) "poner el asunto en conocimiento de las autoridades competentes a los efectos de su investigación o enjuiciamiento" 33 . Cada uno de estos deberes constituye una hipótesis fáctica independiente, de manera que, al menos teóricamente, el incumplimiento de cualquiera de ellas podría dar lugar a la responsabilidad penal o disciplinaria del superior (claro está, de cumplirse los demás requisitos). De hecho, para que haya responsabilidad del superior jerárquico podría no necesitarse que estos deberes recaigan sobre la misma persona. En consecuencia, podría ser posible que un superior deba responder al no haber cumplido con el deber de reprimir o reportar/informar, sin que esa misma persona haya sido quien estaba llamada a prevenir la comisión de los crímenes en cuestión (successor superior responsibility) $^{34}$. De hecho, por esta razón, la

33 Artículo 28 (a) (ii) ECPI para superiores de carácter militar y artículo 28 (b) (iii) ECPI para superiores de carácter civil.

34 En este sentido ICTY, Prosecutor v. Dario Kordić and Mario Čerkez (IT-95-14/2-T), Trial Chamber, Judgment, 26 February 2001, para. 446. Sin embargo, la Cámara de Apelaciones del TPIY negó esta posibilidad en Prosecutor v. Hadžihasanović y otros, nota al pie 28, para. 37 ss., con votos parcialmente disidentes de los jueces Mohamed Shahabuddeen y David Hunt. Posteriormente, la Cámara de Juicio II del TPIY reiteró el criterio inicial en Prosecutor v. Orić al afirmar: "[...] a superior's duty to punish is not derived from a failure to prevent the crime, 
DRSJ ha sido objeto de varias críticas, pues el principio de culpabilidad, según el cual (en términos generales) solamente se le debe imponer al autor la pena que él o ella merecen de acuerdo con lo que él o ella han hecho ${ }^{35}$, parece quedar en entredicho cuando a una persona se le reprocha penalmente un resultado a cuya realización no ha contribuido de alguna manera y, como se verá más adelante, tal vez ni conocía ${ }^{36}$.

Debido a este tipo de problemas, con el paso del tiempo se han decantado poco a poco algunos elementos (objetivos y subjetivos) de la DRSJ, mediante los cuales se busca "reconciliar" esta forma de responsabilidad penal con el principio de culpabilidad. En este sentido, como elementos objetivos, se deben destacar el control efectivo que debe tener el superior sobre el subordinado y la relación de "causalidad" que debe haber entre la omisión del superior y los crímenes cometidos por quienes están bajo su mando. El elemento de control efectivo surge como una forma de concretar y/o complementar el primer requisito de la DRSJ, el cual consiste en que la persona en cuestión efectivamente haya tenido la condición de superior. Para que haya responsabilidad del superior no es suficiente la relación de subordinación en términos formales entre el superior y el subordinado, pues es necesario que el superior (de jure o de facto) esté en capacidad desde el punto de vista material — es decir, fáctico — de prevenir la comisión de los crímenes o de sancionar a quienes los cometan ${ }^{37}$. Esto se debe determinar teniendo en cuenta las

but rather is a subsidiary duty of its own". ICTY, Prosecutor v. Naser Orić (IT-03-68-T), Trial Chamber II, Judgement, 30 June 2006, para. 335. Al respecto, Kai Ambos, nota al pie 31, p. 219220. Robert Cryer y otros, nota al pie 26, p. 387-388. Antonio Cassese, Cassese's International Criminal Law, 192 ( $3^{\text {a }}$. ed., Oxford University Press, Oxford, 2013). Ilias Bantekas, nota al pie 31, p. 93-95. Críticas al respecto, Darryl Robinson, nota al pie 26, p. 20-23.

35 Sobre el principio de culpabilidad, ver el estudio detallado de Arthur Kaufmann ("Der Mensch ist aus Selbstverwirklichung und Selbstvervollkommnung angelegt, er entscheidet frei über die Ziele seines Handelns und ist daher verantwortlich für seine Entscheidungen. Aus diesem Grunde ist er auch schuldfähig [...] Strafe ist die vierdiente Antwort auf die Schuld [...]”. Arthur Kaufmann, Das Schuldprinzip. Eine strafrechtlich-rechtsphilosophische Untersuchung, 208 ( $2^{\text {nd }}$ ed., Carl Winter Universitätsverlag, Heidelberg, 1976).

36 Sobre los problemas de la DRSJ a la luz del principio de culpabilidad, Mirjan R. Damaška, The Shadow Side of Command Responsibility, 49 American Journal of Comparative Law, 455-496, p. 456, 463-464, 468, 479 (2001). Thomas Weigend, nota al pie 26, p. 1024 ss.

37 En este sentido ICTY, Prosecutor v. Zejnil Delalić, Zdravko Mucić (Aka "Pavo"), Hazim Delić and Esad Landžo (Aka "Zenga") ("Čelebići Case") (IT-96-21-A), Appeals Chamber, Judgement, 
circunstancias de cada caso concreto ${ }^{38}$. Respecto al elemento de "causalidad" es necesario precisar que este fue introducido por el ECPI; ninguno de los demás estatutos de tribunales penales internacionales, ni siquiera el PA I, hace referencia a dicho requisito ${ }^{39}$. La "causalidad", como elemento de la DRSJ, se deriva entonces directamente del artículo 28 ECPI, el cual dispone que para que haya responsabilidad penal del superior, los crímenes cometidos por los subordinados deben haber tenido lugar "en razón de no haber ejercido un control apropiado" (cursivas por fuera del texto original) sobre las fuerzas bajo su mando. Esto se ve tal vez con más claridad en la versión en inglés del ECPI, en la cual se utiliza la expresión "as a result of [...]" $]^{\text {"40 }}$. Se debe anotar que este elemento es especialmente relevante para los casos en que el superior incumple el deber de evitar la comisión de los crímenes. Pero, según algunos pronunciamientos del TPIY, los cuales fueron reiterados por la Cámara de Cuestiones Preliminares II de la CPI respecto a este punto, no ocurre lo mismo cuando se trata del deber de reprimir o de informar, pues en estos casos los crímenes ya se han cometido ${ }^{41}$ (a no ser que la falta de sanción o de denuncia constituya una forma de incentivar la comisión de nuevos crímenes) ${ }^{42}$. De cualquier manera, cuando se habla de "causalidad" como elemento de la responsabilidad del superior, se está queriendo decir que la falta

20 February 2001, para. 256. ICTR, Prosecutor v. André Ntagerura, Emmanuel Bagambiki and Samuel Imanishimwe (ICTR-99-46-A), Appeals Chamber, Judgement, 7 July 2006, para. 342. ICTR, Prosecutor v. François Karera (ICTR-01-74-T), Trial Chamber I, Judgement and Sentence, 7 December 2007, para. 564.

38 Robert Cryer y otros, nota al pie 26, p. 387. Kai Ambos, nota al pie 31, p. 211.

39 De hecho, este elemento tampoco constituía un requisito conforme al Derecho Internacional consuetudinario. Gerhard Werle, nota al pie 31, p. 257. En este sentido, ICTY, Prosecutor v. Zejnil Delalić, Zdravko Mucić (Aka “Pavo"), Hazim Delić and Esad Landžo (Aka “Zenga”) (“Čelebići Case”) (IT-96-21-T), Trial Chamber, Judgement, 16 November 1998, para. 398.

40 En este sentido Thomas Weigend, nota al pie 26, p. 1818. Otto Triffterer, Causality, a Separate Element of the Doctrine of Superior Responsibility as Expressed in Article 28 Rome Statute?, 15 Leiden Journal of International Law, 1, 179-205, p. 179 (2002).

41 ICTY, Prosecutor v. Zejnil Delalić et al., nota al pie 39, para. 400. ICTY, Prosecutor v. Naser Orić, nota al pie 34, para. 338. ICC, Prosecutor v. Jean-Pierre Bemba Gombo (ICC-01/0501/08), Pre-Trial Chamber II, Decision Pursuant to Article 61(7)(a) and (b) of the Rome Statute, 15 June 2009, para. 424. Críticas al respecto, Darryl Robinson, nota al pie 26, p. 27-28.

42 Otto Triffterer, nota al pie 40, p. 201-202. Sobre esta posibilidad, Mirjan R. Damaška, nota al pie 36, p. 467-468. Darryl Robinson, nota al pie 26, p. 17. 
de supervisión o control por parte del superior debe explicar en alguna medida la comisión de los crímenes ${ }^{43}$. La pregunta necesaria es, por consiguiente, ¿hasta qué punto la omisión del superior debe ser la causa de la conducta de los subordinados? En otras palabras: ¿qué tan fuerte debe ser este vínculo entre la omisión del superior y la acción del subordinado? Al respecto, se debe afirmar que al tratarse de responsabilidad penal por omisión, el nexo de "causalidad" que se exige en el marco del artículo 28 ECPI es hipotético e invertido ${ }^{44}$, es decir, lo relevante es demostrar que si el superior hubiera cumplido su deber, los crímenes no se hubieran cometido. Al respecto, surgen entonces las dos posibilidades conocidas en la teoría general de los delitos de omisión. Es decir, o se exige un estándar estricto, según el cual es necesario probar que el cumplimiento del deber por parte del superior, con un alto grado de probabilidad (cercano a la certeza), habría evitado el resultado ${ }^{45}$, o se acoge la denominada teoría del aumento del riesgo (o mejor, teoría de la disminución del riesgo, por tratarse de una omisión) ${ }^{46}$, según la cual sería suficiente con probar que, de haber tenido lugar la conducta debida, el riesgo de que se hubiera cometido el crimen habría disminuido, aunque no sea posible afirmar con un alto grado de probabilidad que el resultado se habría podido evitar ${ }^{47}$. Este último criterio fue acogido por la Cámara de Cuestiones Preliminares II de la CPI en la decisión de confirmación de cargos en el caso Bemba Gombo: "the Chamber considers that it is only necessary to prove that the commander's omission increased the risk of the commission of the crimes charged in order to hold him criminally responsible under article 28(a) of the Statute"48.

43 Thomas Weigend, nota al pie 26, p. 1017 ss.

44 En este sentido, Kai Ambos, nota al pie 31, p. 215. Debido a la imposibilidad de probar empíricamente el nexo de causalidad cuando se está ante una omisión, en la doctrina se habla también de Quasi-Kausalität, cuasicausalidad. Uwe Murmann, Grundkurs Strafrecht, 439 (3ª ed., C. H. Beck, München, 2015).

45 Otto Triffterer \& Roberta Arnold, nota al pie 27, p. 1096-1097. En general, sobre el problema de la causalidad en los delitos de omisión, Claus Roxin, Strafrecht. Allgemeiner Teil, Band II: Besondere Erscheinungsformen der Straftat, 639 (C. H. Beck, München, 2003).

46 Roxin hace referencia en este sentido a la Risikoverminderungslehre. Ibíd., p. 644.

47 Ibíd., p. 643 ss.

48 ICC, Prosecutor v. Jean-Pierre Bemba Gombo, nota al pie 41, para. 425. Frente a la teoría del 
Así pues, tanto la exigencia de que el superior realmente haya tenido la posibilidad de evitar los crímenes dado el tipo de control que estaba en capacidad de ejercer así como la necesidad de un nexo de "causalidad" entre el incumplimiento del deber (¿de evitar?) y la acción de los subordinados permiten afirmar, que en el desarrollo de la DRSJ ha existido un esfuerzo para impedir que esta se reduzca a una forma de responsabilidad por el hecho ajeno o vicarious liability ${ }^{49}$.

Con relación al elemento subjetivo se debe precisar que el artículo 28 ECPI prevé varias posibilidades, las cuales varían dependiendo de si el superior tiene carácter militar o civil ${ }^{50}$. Según el artículo 28 (a) (i) el jefe militar será penalmente responsable en cualquiera de los siguientes casos: (i) si "hubiere sabido" o (ii) si "en razón de las circunstancias del momento, hubiere debido saber" que las fuerzas bajo su mando estaban cometiendo crímenes de competencia de la CPI o se proponían cometerlos. De forma similar el artículo 28 (b) (i) dispone con relación a los jefes que no tienen carácter militar, que estos serán penalmente responsables si (i) hubieren "tenido conocimiento" o (ii) si "deliberadamente" hubieren "hecho caso omiso de información que

aumento del riesgo se ha planteado la objeción de que lesiona el principio in dubio pro reo (con relación al DPI Thomas Weigend, nota al pie 26, p. 1818) y que en los casos de comisión por omisión transforma los delitos de resultado en delitos de peligro (Uwe Murmann, nota al pie 44, p. 440).

49 ICTY, Prosecutor v. Zejnil Delalić et al., nota al pie 37, para. 239. El concepto de vicarious liability es propio de la responsabilidad civil extracontractual. Con relación a la aplicación (cuestionada) en el Derecho Penal inglés, Dennis J. Baker, Glanville Williams Textbook of Criminal Law, 1297 (3 $3^{\text {rd }}$ ed., Sweet \& Maxwell, London, 2012). Andrew Ashworth \& Jeremy Horder, Principles of Criminal Law, 149-150 ( $7^{\text {th }}$ ed., Oxford University Press, Oxford, 2013).

50 De acuerdo con Jenny S. Martínez, este ha sido el elemento más discutido de la DRSJ. Ver Jenny S. Martínez, Understanding Mens Rea in Command Responsibility. From Yamashita to Blaškić and beyond, 5 Journal of International Criminal Justice, JICJ, 638-664, p. 640 (2007). En buena parte, las confusiones se deben, por un lado, a las diferencias en los textos de los estatutos de los tribunales ad hoc y el ECPI y, por otro lado, a las divergencias entre las categorías nacionales mediante las cuales se pretende explicar este elemento y que en ocasiones se traducen de forma equivocada o se trasladan sin más al DPI. Este problema se ha presentado incluso en las traducciones de las decisiones de los tribunales internacionales. El ejemplo mencionado por Jenny S. Martínez sobre este punto es bastante ilustrativo: en la versión en francés de la decisión de primera instancia del TPIY en el caso Blaškić se hace referencia al dolo eventual (dol éventuel) en los parágrafos 474 y 562, pero en la versión en inglés esto se traduce de dos formas distintas (¡en la misma decisión!); en el parágrafo 474 aparece como recklessness, mientras que en el parágrafo 562 se traduce como negligence. International Criminal Tribunal for the former Yugoslavia, ICTY, Prosecutor v. Blaškić (IT-95-14-T), Trial Chamber, Judgement, 3 March 2000. 
indicase claramente que los subordinados estaban cometiendo esos crímenes o se proponían cometerlos". Estos supuestos se pueden presentar en combinación con cualquiera de los deberes cuyo incumplimiento puede fundamentar la responsabilidad penal del superior, lo cual podría dar lugar a por lo menos cuatro situaciones distintas. Así, por ejemplo, en el caso de un superior militar es posible afirmar que este es responsable penalmente por no haber evitado la comisión de crímenes por parte de sus subordinados, a pesar de que sabía que estos crímenes se estaban cometiendo (situación 1), o debido a que, si bien no sabía, en todo caso "hubiere debido saber" (situación 2); o por no haber tomado las medidas necesarias para reprimir estos crímenes o informar a las autoridades competentes al respecto, estando al tanto de que estos crímenes se estaban cometiendo (situación 3), o sin estarlo pero bajo el entendido de que según las circunstancias del momento "hubiere debido" estarlo (situación 4).

De lo dispuesto en el artículo 28 ECPI con relación al elemento subjetivo surgen entonces dos preguntas: ¿Qué significa la expresión "hubiere debido saber" contenida en el artículo 28 (a) (i)? y jeste elemento es diferente al elemento "deliberadamente hubiere hecho caso omiso" del artículo 28 (b) (i)? Para responder estos interrogantes se pueden tener en cuenta las cuatro formas tradicionales de mens rea del Derecho Penal angloamericano ${ }^{51}$ (intent, knowledge, recklessness, negligence) tal como fueron definidas, por ejemplo, en el Código Penal Modelo (Model Penal Code, MPC) de Estados Unidos de América ${ }^{52}$, dado que el ECPI $\mathrm{y}$, en general, el DPI en varios aspectos son más cercanos a este tipo de categorías ${ }^{53}$. Por intención o intent se puede entender

$51 \mathrm{Al}$ margen de las diferencias que hay entre los sistemas jurídicos concretos que pertenecen al Common Law. Al respecto, Jenny S. Martínez, nota al pie 50, p. 645-647.

52 La sección 2.02 del MPC (el cual fue finalizado en 1962 por el American Law Institute) define cuatro formas de culpabilidad (minimum requirement of culpability) y establece que nadie puede ser condenado penalmente a no ser que haya actuado purposely, knowingly, recklessly o negligently. American Law Institute, Model Penal Code and Commentaries, Part I, 225 (The American Law Institute, Philadelphia, 1985).

53 Al respecto y sobre la necesidad de acudir al análisis comparado del Derecho como base para el estudio del DPI, Kai Ambos, Der Allgemeine Teil des Völkerstrafrechts. Ansätze einer Dogmatisierung, 44-48, 71-72 (2 ed., Duncker \& Humblot, Berlin, 2004). Sobre el MPC y la DRSJ, Kai Ambos, nota al pie 31, p. 224-225. 
la determinación o decisión de llevar a cabo una determinada conducta $^{54}$. Conocimiento o knowledge puede ser definido, de acuerdo con el artículo 30 (3) ECPI, como "la conciencia de que existe una circunstancia o se va a producir una consecuencia en el curso normal de los acontecimientos". A su turno, recklessness supone que el autor no desea una determinada consecuencia o resultado dañoso, pero a pesar de esto asume el riesgo (injustificado) y realiza la conducta ${ }^{55}$. Mientras que negligencia o negligence consiste en el incumplimiento del deber de cuidado que una persona razonable y prudente tendría ante una situación similar $^{56}$. Se ha sostenido entonces que la expresión "hubiere debido saber" del artículo 28 (a) (i) corresponde al estándar de negligencia (a diferencia de lo dicho por los tribunales ad-hoc con

54 Según el Black's Law Dictionary: "While motive is the inducement to do some act, intent is the mental resolution or determination to do it". Bryan A. Garner (editor in chief), Black's Law Dictionary, 930 (10 ${ }^{\text {th }}$ ed., Thomson Reuters, Saint Paul, Minnesota, 2014).

55 Según el Black's Law Dictionary se puede hablar de recklessness cuando: "the actor does not desire the harmful consequence but nonetheless foresees the possibility and consciously takes the risk". Ibíd., p. 1462. Tal vez uno de los términos del Derecho Penal angloamericano más difíciles de traducir al español es el de recklessness. En ocasiones, este concepto se ha asimilado al de dolo eventual (por ejemplo, Antonio Cassese, nota al pie 34, p. 44 ss.), mientras que para algunos autores correspondería a la culpa consciente [George P. Fletcher \& Jens David Ohlin, Reclaiming Fundamental Principles of Criminal Law in the Darfur Case, 3 Journal of International Criminal Justice, JICJ, 539-561, p. 554 (2005)]. De hecho, ni en la literatura ni en la jurisprudencia angloamericana hay acuerdo sobre el significado exacto y los límites de esta forma de imputación subjetiva (Andrew Ashworth \& Jeremy Horder, nota al pie 49, p. 175 ss.). Sin embargo, se debe tener en cuenta que recklessness supone un nivel menor de reprochabilidad que intent y knowledge (Dennis J. Baker, nota al pie 49, p. 119), razón por la cual no parece apropiado definirlo como dolo eventual, menos aún si se tiene en cuenta que en los sistemas penales de influencia europea continental el dolo eventual es finalmente una forma de dolo y, por lo tanto, por lo general se sanciona igual que el dolo directo. Por esta razón, posiblemente es mejor entenderlo como una forma de responsabilidad equivalente a la culpa consciente, sin perder devista que de todas maneras constituye una forma de responsabilidad intermedia entre intent y negligence. En todo caso, se debe resaltar que el elemento que distingue esta forma de responsabilidad es el hecho de conocer o ser consciente de un riesgo injustificado. En este sentido, en el comentario al MPC, se afirma: "[...] recklessness involves conscious risk creation. It resembles acting knowingly in that a state of awareness is involved, but the awareness is of risk [...]". Model Penal Code and Commentaries, nota al pie 52, p. 236.

56 Según el Black's Law Dictionary: "The failure to exercise the standard of care that a reasonably prudent person would have exercised in a similar situation". Black's Law Dictionary, nota al pie 54, p. 1196. Al respecto, Dennis J. Baker, nota al pie 49, p. 123 ss. Según Baker, es posible afirmar incluso que negligence no es una forma de mens rea, ya que únicamente exigiría la constatación objetiva de la existencia e incumplimiento de un deber de cuidado. Según el comentario del MPC: "It is distinguished from purposeful, knowing or reckless action in that it does not involve a state of awareness". Model Penal Code and Commentaries, nota al pie 52, p. 240. 
relación a sus estatutos $)^{57}$, mientras que la frase "deliberadamente hubiere hecho caso omiso" estaría más cercana a recklessness ${ }^{58}$. En este sentido, es interesante ver la similitud de la versión en inglés del ECPI con el MPC: en el artículo 28 (a) (i) ECPI se lee "That military commander [...] should have known", mientras que en la sección 2.02 (2) (d) MPC al definir negligence se usa la expresión "when he should be aware"; de manera similar, el artículo 28 (b) (i) ECPI dice "consciously disregarded information which clearly indicated", mientras que en la sección 2.02 (2) (c) sobre recklessness se establece: "when he consciously disregards a substantial and unjustifiable risk". El artículo 28 ECPI prevé, en consecuencia, dos estándares de elemento subjetivo, diferentes a los definidos en el artículo 30 ECPI, el cual establece la intención y el conocimiento como regla general con relación a los crímenes de competencia de la Corte, pero admite excepciones al decir "salvo disposición en contrario". El elemento subjetivo de los superiores no militares es entonces más estricto que el de los superiores militares, pues para que haya responsabilidad penal en el primer caso se requiere un estándar más alto que en el segundo. De ahí que, en el contexto de la CPI, el incumplimiento negligente de los deberes de prevención y sanción por parte de un superior no militar no sea punible. El factor decisivo sería entonces la calidad de la información que está a disposición del

57 Kai Ambos, nota al pie 31, p. 221 ss.; Robert Cryer y otros, nota al pie 26, p. 388-390. Gerhard Werle, nota al pie 31, p. 252-254. Ilias Bantekas, nota al pie 31, p. 88-91 (Para Bantekas este estándar debe ser interpretado como gross negligence). Este no ha sido un punto pacífico en la jurisprudencia de los tribunales $a d-h o c$. Al respecto se ha afirmado, por ejemplo, que la negligencia debe ser tan grave como para equipararse a la intención maliciosa. En este sentido ver ICTR, Prosecutor v. Jean-Paul Akayesu, nota al pie 29, para. 488. En esta misma decisión, el TPIR también hizo hincapié en que para los crímenes de su competencia era necesario obrar con criminal intent (Ibíd., para. 489). En todo caso, la Cámara de Apelaciones del TPIR negó posteriormente el estándar de negligencia (ICTR, Prosecutor v. Ignace Bagilishema (ICTR95-1A-A), Appeals Chamber, Judgement, 3 July 2002, para. 35), lo cual fue reiterado en el contexto del Tribunal para la ex Yugoslavia (ICTY, Prosecutor v. Blaškić (IT-95-14-A), Appeals Chamber, Judgement, 29 July 2004, para. 63). No obstante, al parecer, en este mismo proceso se había afirmado lo contrario (ICTY, Prosecutor v. Blaškić, nota al pie 50, para. 332). En detalle, al respecto, Jenny S. Martínez, nota al pie 50, p. 654 ss. En todo caso, en el contexto del ECPI se reconoció el estándar de negligencia para los superiores militares en CPI, Prosecutor v. Jean-Pierre Bemba Gombo, nota al pie 41, para. 429.

58 Kai Ambos, nota al pie 31, p. 227. Chantal Meloni, Command Responsibility. Mode of Liability for the Crimes of Subordinates or Separate Offence of the Superior?, 5 Journal of International Criminal Justice, 619-637, p. 634-635 (2007). 
superior. En el caso de un superior militar cualquier tipo de información más o menos confiable debe ser tenida en cuenta y este está obligado a corroborarla ${ }^{59}$. Incluso se ha llegado a afirmar que los superiores militares tienen el "deber de conocer", o sea, de buscar información sobre lo que hacen sus subordinados ${ }^{60}$. En cambio, tratándose de superiores no militares, según el mismo artículo 28 ECPI, solamente puede haber responsabilidad, si había información a disposición del sujeto y esa información indicaba "claramente que los subordinados estaban cometiendo" crímenes "o se proponían cometerlos". De todas maneras, aquí se quiere resaltar que ni para los superiores militares ni para los superiores civiles la DRSJ supone una forma de responsabilidad estricta o strict liability ${ }^{61}$.

Con base en estas precisiones es posible plantear la pregunta sobre el tipo de responsabilidad que implica la DRSJ. Como se ha dicho, esta constituye una forma de responsabilidad por omisión. Sin embargo, se debe advertir que la misma tiene un carácter sui generis ${ }^{62}$, en la medida en que envuelve elementos de varias formas de responsabilidad contempladas normalmente en los ordenamientos jurídicos internos. Por consiguiente, la pregunta central a este respecto es si el superior responde penalmente por los crímenes cometidos por los subordinados, de manera que se pueda hablar de una suerte de participación en un hecho ajeno (cercana a la complicidad) ${ }^{63}$, o si se trata más bien de un tipo de responsabilidad autónoma del superior, la cual surge por el hecho mismo del incumplimiento de sus deberes de vigilancia,

59 Kai Ambos, nota al pie 31, p. 224-225 (referencias jurisprudenciales en el pie de página 426).

60 Esto lo negó el Tribunal para la ex Yugoslavia en ICTY, Prosecutor v. Zejnil Delalić et al., nota al pie 39, para. 393. Sin embargo, al contrario, ICTY, Prosecutor v. Blaškić, nota al pie 50, para. 332, y ICC, Prosecutor v. Jean-Pierre Bemba Gombo, nota al pie 41, para. 432-433. Para ver argumentos a favor del deber de conocer por parte de superiores militares ver Jenny S. Martínez, nota al pie 50, p. 660 ss.

61 En este sentido, ICTY, Prosecutor v. Zejnil Delalić et al., nota al pie 37, para. 239. Casos de strict liability son aquellos en los cuales no es necesario probar que la persona actuó con intent, knowledge, recklessness o negligence. Sobre strict liability, Andrew Ashworth \& Jeremy Horder, nota al pie 49, p. 160 ss.

62 Al respecto, Chantal Meloni, nota al pie 58, p. 619.

63 A favor de concebir la DRSJ como una forma de responsabilidad accesoria, Darryl Robinson, nota al pie 26 . 
control y sanción ${ }^{64}$. Este problema surgió desde los procesos penales que tuvieron lugar después de la Segunda Guerra Mundial $^{65}$. En los trabajos de la International Law Commission ${ }^{66}$ (ILC) y en parte de la jurisprudencia del TPIY, la DRSJ fue interpretada como una forma de responsabilidad en la que el superior responde por los crímenes cometidos por quienes están bajo su mando ${ }^{67}$. Sin embargo, en algunas de sus decisiones, el TPIY dio un giro hacia un entendimiento más independiente de la DRSJ, según el cual el fundamento de la responsabilidad del superior estaría en el incumplimiento de los deberes que emanan de su condición y, por tanto, esta no podría ser igual a la responsabilidad de quienes efectivamente cometieron los crímenes $^{68}$. Esta disyuntiva es relevante en la medida en que los requisitos que dan lugar a la responsabilidad del superior pueden ser interpretados de una $\mathrm{u}$ otra manera dependiendo del enfoque del que se parta. Así, si se entiende que el superior responde por los crímenes de sus subordinados, debe haber entonces un vínculo más o menos estrecho, tanto desde el punto de vista objetivo como subjetivo, entre el incumplimiento de los deberes por parte del superior y el resultado criminal causado por la acción de los subalternos ${ }^{69}$. En este caso, cobran mayor relevancia la discusión sobre la "causalidad" en los delitos de

$64 \mathrm{Al}$ respecto, Chantal Meloni, nota al pie 58, p. 620. Sobre el argumento según el cual la DRSJ constituye un tipo de crimen en particular, Darryl Robinson, nota al pie 26, p. 30 ss.

65 Chantal Meloni, nota al pie 58, p. 621-623.

66 De hecho, en el proyecto de Código de Crímenes contra la Paz y Seguridad de la Humanidad presentado en 1996 por la ILC se preveía en el artículo 2, en el cual se definían las distintas formas de intervención, apartado (3) (c), la responsabilidad penal por los delitos contemplados en los artículos 17 (genocidio), 18 (crímenes contra la humanidad), 19 (crímenes contra las Naciones Unidas) y 20 (crímenes de guerra) de quien fallara al prevenir o reprimir la comisión de uno de estos crímenes, de acuerdo a las circunstancias descritas en el artículo 6. Ver: Organización de Naciones Unidas, ONU, Comisión de Derecho Internacional, Yearbook of the International Law Commission, Vol. II, Part Two, Informe de la Comisión a la Asamblea General sobre la labor realizada en su 48 período de sesiones, 17-56, 18-22, 25-26 (1996).

67 Chantal Meloni, nota al pie 58, p. 621 ss. En este sentido: ICTY, Prosecutor v. Zejnil Delalić et al., nota al pie 39, para. 331-333. ICTY, Prosecutor v. Zejnil Delalić et al., nota al pie 37, para. 198.

68 ICTY, Prosecutor v. Naser Orić, nota al pie 34, para. 293. También ICTY, Prosecutor v. Sefer Halilović (IT-01-48-T), Trial Chamber I, Judgement, 16 November 2005, para. 54. ICTY, Prosecutorv. Enver Hadžihasanović and Amir Kubura (IT-01-47-T), Trial Chamber, Judgement, 15 March 2006, para. 2075.

69 Chantal Meloni, nota al pie 58, p. 628 ss. 
omisión $^{70}$ y la pregunta sobre hasta qué punto el superior debe conocer los elementos del crimen cometido por sus subalternos o incluso hasta qué punto es necesario que él también quiera la producción del resultado ${ }^{71}$. De lo contrario, si se entiende que el superior responde por un delito propio, este vínculo (objetivo y subjetivo) no sería necesario o por lo menos no tendría que ser tan evidente ${ }^{72}$. En todo caso, así se siga este último enfoque, y aquí se evidencia el carácter sui generis de la DRSJ, siempre se requiere que los subordinados efectivamente cometan un crimen internacional.

En el marco del ECPI, se debe afirmar que el artículo 28 contempla una forma especial de responsabilidad (o de imputación) y no un crimen (de omisión) adicional a los denominados core crimes $^{73}$. Esto se desprende de una interpretación literal de esta norma en la que se establece que "el jefe militar será penalmente responsable por los crímenes de la competencia de la Corte que hubieren sido cometidos por fuerzas bajo su mando [...]" (cursivas por fuera del texto original). De ahí que, como ya se explicó, la misma disposición exija una suerte de nexo de "causalidad" al decir "en razón de no haber ejercido un control apropiado sobre esas fuerzas". En consecuencia, si de forma intencional el superior no ejerce el control necesario para prevenir, no habría problema en considerarlo responsable por los crímenes que efectivamente fueron cometidos, lo cual podría ser a título de complicidad (si se prueba que el incumplimiento del deber tuvo lugar "con el propósito de facilitar la comisión" en los términos del artículo 25 (2) (c)) $)^{74}$ o a título de autoría (si se asume que el superior está en posición de garante) ${ }^{75}$. Sobre esto último, el

\footnotetext{
70 Sobre el requisito de causalidad y su importancia con miras al principio de culpabilidad en el contexto de la DRSJ, Darryl Robinson, nota al pie 26, p. 12 ss.

71 Chantal Meloni, nota al pie 58, p. 628-631.

72 En este supuesto tiene más sentido exigir solamente un conocimiento general sobre la comisión de los crímenes y no un conocimiento específico con relación a cada uno de sus elementos. Ibíd., p. 631.

73 Ibíd., p. 633.

74 Ibíd., p. 635. Kai Ambos, nota al pie 31, p. 230-231. Antonio Cassese, nota al pie 34, p. 191. En este sentido, pero sin referirse concretamente al ECPI, Mirjan R. Damaška, nota al pie 36, p. 462.

75 Kai Ambos, nota al pie 31, p. 206, 230-231.
} 
ECPI no dice nada explícitamente. Sin embargo, si la omisión del superior no es intencional sino negligente de acuerdo con la expresión "hubiere debido saber", se podría discutir sobre si en este contexto es posible hablar de intervención negligente en un delito doloso ${ }^{76}$ o si en este caso sí sería más apropiado entender la responsabilidad del superior como una forma de responsabilidad específica con fundamento en el incumplimiento de un deber ${ }^{77}$. Este mismo interrogante surge con más fuerza cuando se trata solamente del incumplimiento del deber de reprimir o sancionar (de aceptarse esta posibilidad), ya que aquí la distancia entre los crímenes efectivamente cometidos y la omisión del superior es aún mayor ${ }^{78}$. Por esto, algunos autores han sostenido que el requisito de causalidad, tal como fue previsto en el artículo 28 ECPI, también debe ser relevante con relación al deber de reprimir, pues en estos casos el superior no debería responder por crímenes pasados (a cuya consumación no contribuyó, a pesar de no haber sancionado a sus perpetradores), sino por la consumación de crímenes subsiguientes a los que haya contribuido al no sancionar a quienes cometieron crímenes en el pasado ${ }^{79}$. En todo caso, el ECPI no admite la complicidad culposa; tampoco hay una modalidad culposa de los crímenes de competencia de la Corte. Por esta razón, y a pesar de los problemas que de aquí surgen a la luz del principio de culpabilidad (sobre todo cuando la omisión consiste en no reprimir o no informar), esta circunstancia debe ser tenida en cuenta en el momento de imponerse la sanción, para lo cual, según el artículo 78.1 del ECPI, se debe tomar en consideración la gravedad del crimen ${ }^{80}$.

76 Damaška cuestiona esta posibilidad, debido a que viola el principio de culpabilidad. Mirjan R. Damaška, nota al pie 36, p. 463-465, 480.

77 En este sentido, Chantal Meloni, nota al pie 58, p. 635.

78 Ibíd., p. 636. Antonio Cassese, nota al pie 34, p. 192. Mirjan R. Damaška, nota al pie 36, p. 479.

79 Darryl Robinson, nota al pie 26, p. 56-57. Sin embargo, al parecer la Cámara de Cuestiones Preliminares II de la CPI no siguió esta interpretación. Ver: CPI, Prosecutor v. Jean-Pierre Bemba Gombo, nota al pie 41, para. 424.

80 Varios autores han reconocido que la DRSJ envuelve varios tipos de responsabilidad y que por lo tanto en el momento de imponerse la sanción se debe diferenciar entre las diferentes hipótesis fácticas y su gravedad. Por ejemplo, en este sentido, Kai Ambos, nota al pie 31, p. 231. Antonio Cassese, nota al pie 34, p. 192. 


\section{RESPONSABILIDAD PENAL POR OMISIÓN DE MIEMBros de la Fuerza PÚBlicA en COLOMBIA: DESARROLLO JURISPRUDENCIAL DEL ARTÍCULO 25 del Código Penal colombiano}

La responsabilidad penal por omisión de miembros de la Fuerza Pública frente a violaciones de DDHH o infracciones graves al DIH se ha tratado en Colombia por medio del artículo 25 CPC, el cual regula la omisión impropia o comisión por omisión y establece los casos en los que una persona está en posición de garante $^{81}$. Esta norma ha sido interpretada tanto por la Corte Constitucional como por la Corte Suprema de Justicia (CSJ) conforme al planteamiento del profesor alemán Günther Jakobs, específicamente a partir de la distinción que este hace entre competencia por organización y competencia institucional como fundamentos de la responsabilidad penal ${ }^{82}$. Sin embargo, se debe advertir que la jurisprudencia colombiana se ha centrado en eventos de omisión frente a conductas delictivas de terceros a quienes la Fuerza Pública debe combatir y no en la omisión del superior con relación a las conductas delictivas de sus subordinados. Al parecer, con relación a este último punto, el cual corresponde en el ámbito internacional a la DRSJ, no hay en Colombia un desarrollo jurisprudencial específico. En todo caso, a continuación se reconstruirá el argumento general que ha desarrollado la jurisprudencia colombiana sobre la responsabilidad penal por omisión de miembros de la Fuerza Pública,

81 Según el primer párrafo del artículo 25 CPC: "Quien tuviere el deber jurídico de impedir un resultado perteneciente a una descripción típica y no lo llevare a cabo, estando en posibilidad de hacerlo, quedará sujeto a la pena contemplada en la respectiva norma penal. A tal efecto, se requiere que el agente tenga a su cargo la protección en concreto del bien jurídico protegido, o que se le haya encomendado como garante la vigilancia de una determinada fuente de riesgo, conforme a la Constitución o a la ley". Al respecto ver: Juan Carlos Forero-Ramírez, El delito de omisión en el nuevo Código Penal, 97-143 (Legis, Bogotá, 2002). Fernando Velásquez-Velásquez, Derecho penal. Parte general, 662-670 (4 ed., Comlibros, Medellín, 2009). Alejandro Aponte-Cardona, Superior jerárquico, omisión impropia y posiciones de garantía: tensiones actuales entre dogmática y jurisprudencia, en Derecho Penal y Crítica al Poder Punitivo del Estado, Tomo 2, 1079-1111 (Fernando Velásquez, Ricardo Posada, Alfonso Cadavid, Ricardo Molina \& Juan Oberto Sotomayor, eds., Grupo Editorial Ibáñez, Bogotá, 2013).

82 Günther Jakobs, Strafrecht. Allgemeiner Teil: die Grundlagen und die Zurechnungslehre Lehrbuch, 177-183 y 657 ss. (Walter de Gruyter, Berlin, 1983). 
para llamar la atención sobre algunas afirmaciones que la Corte Constitucional y la CSJ han realizado en este contexto y que son problemáticas a la luz del ordenamiento jurídico interno o por lo menos, resultan confusas.

La sentencia de la Corte Constitucional SU-1184 del 13 de noviembre de 2001 constituye la decisión fundacional con relación a la responsabilidad penal por omisión de miembros de la Fuerza Pública, cuando se trata de violaciones de DDHH o infracciones al DIH equivalentes a crímenes internacionales. Esta sentencia es interesante, entre otras razones, porque en ella se analizan aspectos concretos de la responsabilidad penal relacionados con la forma de imputación, pero con el fin de establecer en cuál jurisdicción debían ser investigados y juzgados los hechos en cuestión, la jurisdicción penal ordinaria o la jurisdicción penal militar. La Corte Constitucional discutió en esta decisión sobre dos miembros del Ejército colombiano, un brigadier general y un teniente coronel, que al parecer no realizaron las acciones debidas con el fin de impedir que un grupo paramilitar, el cual se había desplazado de una región de Colombia a otra utilizando incluso varios medios de transporte, cometiera una masacre en una población que mantuvo ocupada por cinco días ${ }^{83}$. El argumento que planteó la Corte Constitucional para establecer que este caso debía ser conocido por la jurisdicción penal ordinaria se puede dividir en cuatro partes o proposiciones: (i) como lo había dicho en decisiones anteriores, la Corte afirma que un delito cometido por un miembro de la Fuerza Pública es de competencia de la justicia penal militar, siempre que haya sido cometido "en el marco de una actividad ligada directamente a una función propia del cuerpo armado", es decir, debe haber "un vínculo claro de origen" entre el crimen y la actividad del servicio ${ }^{84}$; (ii) sin embargo, cuando el delito cometido por un miembro de la Fuerza Pública es especialmente grave, por ejemplo cuando se trata de crímenes de lesa humani-

83 Corte Constitucional, Sentencia SU-1184-01, 13 de noviembre de 2001, magistrado ponente Eduardo Montealegre-Lynett, apartado I. 1.

84 Ibíd., apartado II. 10. a. 
dad, este vínculo se rompe, ya que una conducta que busca fines contrarios a la misión que constitucionalmente le corresponde a la Fuerza Pública debe ser considerada como "un acto fuera del servicio"85; por otro lado, (iii) para efectos penales, cuando una persona está en posición de garante (bien porque tiene a su cargo la protección en concreto de un bien jurídico o porque se le ha encomendado la vigilancia de una determinada fuente de riesgo), es indiferente si ha incumplido sus deberes de forma activa $u$ omisiva ${ }^{86}$; en consecuencia, (iv) cuando un miembro de la Fuerza Pública está en posición de garante, para efectos de establecer si el juzgamiento de su conducta (delictiva) corresponde o no a la justicia penal militar, no importa que se haya apartado de su función constitucional de forma omisiva, ya que, debido a la posición de garante, la acción y la omisión son equivalentes y por consiguiente, al igual que sucede con las conductas activas, la omisión no puede ser considerada como un acto del servicio ${ }^{87}$.

La Corte Constitucional afirma, con razón, que los miembros de la Fuerza Pública pueden tener posición de garante con fundamento en dos posibilidades: o bien porque en el desarrollo de actividades peligrosas han creado riesgos que en principio son permitidos pero de los cuales se derivan deberes de seguridad en el tráfico y, cuando estos fallan, deberes de salvamento (competencia por organización) ${ }^{88}$, o bien porque al pertenecer a una institución básica para la estructura social tienen el deber de "configurar un mundo en común con alguien" y esto supone protegerlo contra los peligros que lo amenacen, independientemente de dónde provengan estos peligros (competencia institucional) ${ }^{89}$. Se debe resaltar que la Corte Constitucional vincula en este punto la DRSJ a la posición de garante con fundamento en la competencia por organización, bajo el

85 Ibíd., apartado II. 10. b.

86 Ibíd., apartado II. 16.

87 Ibíd., apartado II. 20.

88 Ibíd., apartado II. 15. 1 y 17.

89 Ibíd., apartado II. 15. 2 y 17. La Corte Constitucional fundamenta la posición de garante de la Fuerza Pública en las normas constitucionales que determinan sus funciones: artículos 2, 217 y 218 de la Constitución Política. Ibíd., apartado II. 17. c). 
entendido de que el miembro de la Fuerza Pública que tiene mando debe "tomar medidas especiales (deberes de seguridad en el tráfico) para evitar que personas que se encuentran bajo su efectivo control, realicen conductas que vulneren los derechos fundamentales" ${ }^{90}$. Esta asociación es interesante no solamente porque constituye la única consideración específica sobre la DRSJ que se encuentra en la sentencia sino también porque vincula el Derecho Penal nacional con el DPI y proporciona un fundamento teórico común para los casos de responsabilidad (por omisión) del superior. Sin embargo, queda la duda sobre si en estos casos el superior debe ser considerado únicamente autor o únicamente cómplice, o si se pueden dar las dos formas de intervención, ya que según la idea de competencia por organización el garante puede responder en cualquiera de estas dos modalidades, dependiendo de la relevancia de su aporte (en este caso, la omisión) en la producción del resultado ${ }^{91}$. En la sentencia, la Corte Constitucional no aborda ni define este problema. Por otro lado, se debe señalar que la Corte Constitucional aclara, con relación a la posición de garante por competencia institucional, que la posición de garante de los miembros de la Fuerza Pública no debe ser establecida en abstracto sino en concreto, teniendo en cuenta el ámbito de competencia material, funcional y territorial de cada individuo ${ }^{92}$. Tanto en los casos de competencia por organización como institucional, la Corte resalta en esta decisión, el miembro de la Fuerza Pública debe responder penalmente por el resultado lesivo efectivamente producido, por sus subordinados en el primer caso o por terceros en el segundo ${ }^{93}$. Hasta aquí no parece haber mayor problema. Sin embargo, al explicar estas consideraciones, la Corte Constitucional formula dos afirmaciones adicionales (en términos bastante generales) que resultan problemáticas, dado que la Corte no las desarrolla y en consecuencia pueden dar lugar a malas interpretaciones.

\footnotetext{
90 Ibíd., apartado II. 17. a.

91 Günther Jakobs, nota al pie 82, p. 696-697.

92 Corte Constitucional, nota al pie 83, apartado II. 17. b y 20.

93 Ibíd., apartado II. 18 y 20.
} 
La primera de estas afirmaciones dice: "Las fuerzas militares tienen la obligación absoluta de impedir el desconocimiento del derecho internacional humanitario [...] Permitir que ocurran, sea porque activamente intervienen en ellas o porque omiten el deber estatal de proteger a los asociados en sus derechos, constituye una flagrante violación a la posición de garante de las condiciones mínimas y básicas de la organización social [... ${ }^{\prime 94}$. La pregunta a este respecto es qué quiso decir la Corte Constitucional con "obligación absoluta". Esta afirmación puede dar a entender que de no evitar la vulneración de derechos fundamentales (por ejemplo, por medio de violaciones al DIH), los miembros de la Fuerza Pública pueden ser considerados penalmente responsables sin el cumplimiento de más requisitos, puesto que, al "no impedir" hechos de esta clase habrían violado "flagrantemente" la posición de garante en la que ellos están. Al respecto, se debe precisar, que en esta decisión la Corte Constitucional en ocasiones realiza afirmaciones sobre los deberes concretos de los individuos que hacen parte de la Fuerza Pública, pero en otras ocasiones la Corte se refiere de forma general a la función de las Fuerzas Militares como institución (por ejemplo, la referencia a los artículos 2, 217 y 218 Constitución Política), de lo cual no se desprende que para establecer la responsabilidad penal de cada individuo no sea necesario indagar sobre los deberes concretos que este tiene de acuerdo al lugar que ocupa dentro de las Fuerzas Militares. De ahí que la misma Corte Constitucional haya precisado párrafos antes de realizar esta afirmación que siempre se debe establecer en concreto cuál era el ámbito de competencia material, temporal y funcional, para determinar posteriormente si la persona en cuestión efectivamente incumplió los deberes específicos que de allí se derivan ${ }^{95}$. Así pues, desde el punto de vista constitucional, es posible afirmar que la Fuerza Pública (como institución) no puede renunciar a la obligación de proteger a la población civil

94 Ibíd., apartado II. 17. c.

95 Ibíd., apartado II. 17. b. 
y que en este sentido esto constituye una "obligación absoluta", pero esta obligación claramente tiene límites cuando se trata de establecer la responsabilidad penal ante un eventual incumplimiento concreto por parte de un individuo.

La segunda afirmación sobre la cual se quiere llamar la atención (y que resulta más problemática que la anterior) tiene qué ver con la imputación subjetiva. La Corte Constitucional reitera que en casos de responsabilidad penal por omisión "el título de imputación", con relación a miembros de la Fuerza Pública, "se hace por el delito de lesa humanidad" efectivamente cometido ${ }^{96}$. Para aclarar esto, la Corte realiza la siguiente afirmación en la que se refiere a tres temas distintos: "sin importar la forma de intervención en el delito [...] o el grado de ejecución del mismo [...] o la atribución subjetiva"97, y en el párrafo siguiente da tres razones para explicar esta afirmación, cada una de ellas relacionada con uno de los temas recién mencionados. Así, con relación a la atribución subjetiva dice entonces la Corte: "el conocimiento del riesgo (que sirve para deslindar el dolo de la imprudencia) no modifica la naturaleza de la conducta realizada (la grave violación a los derechos humanos)"98. Esta referencia a la atribución subjetiva es problemática por dos motivos: supone una contradicción con el punto de partida de la propia Corte Constitucional y, además, conduce a una conclusión cuestionable a la luz del principio de culpabilidad.

Al parecer, en esta parte de la sentencia, la Corte Constitucional asume que quien incurre en una omisión estando en posición de garante (el miembro de la Fuerza Pública) tiene calidad de partícipe y que solo serían autores quienes realizan materialmente el crimen (los miembros del grupo armado ilegal). Esto no lo afirma la Corte Constitucional expresamente, pero se puede inferir de la forma como en la sentencia se explica por qué el militar responde por el delito de lesa humanidad efectivamente cometido. Al respecto, sostiene la Corte Constitucional, en pri- 
mer lugar, que "el autor y el partícipe intervienen en un hecho único, porque el destinatario de la imputación es el colectivo que lo realiza; el cómplice y el determinador no realizan un injusto autónomo"99. Seguidamente, la Corte sostiene que en los casos de tentativa "el injusto del hecho solo se diferencia de la consumación cuantitativamente" ${ }^{100} \mathrm{y}$ después hace en el mismo párrafo la referencia a la atribución subjetiva ya citada. Lo que no queda claro, entonces, es por qué para la Corte "el conocimiento del riesgo [...] no modifica la naturaleza de la conducta realizada" y por qué "el título de imputación [...] se hace por el delito de lesa humanidad [...] sin importar [...] la atribución subjetiva". La única razón visible es que al realizar esta afirmación la Corte Constitucional aún está hablando de casos de responsabilidad penal accesoria, lo cual, en todo caso, tampoco sería una razón adecuada para llegar a esta conclusión.

Al respecto, se debe advertir que si el sujeto que omite es considerado garante por competencia institucional, necesariamente debe ser considerado autor del resultado antijurídico. A pesar de que la intervención omisiva en un delito activo aún es un punto discutido en la doctrina alemana ${ }^{101}$, así se desprende del planteamiento de Günther Jakobs ${ }^{102}$, a quien la misma Corte Cons-

99 Ibíd., apartado II. 18.

100 Ibíd., apartado II. 18.

101 Al respecto, Johannes Wessels, Werner Beulke \& Helmut Satzger, Strafrecht. Allgemeiner Teil, 349 (45 $\mathrm{a}$ ed., C. F. Müller, Heidelberg, 2015). Algunos autores consideran que el garante que omite y así contribuye a la consumación (activa) de un tipo penal por parte de otra persona siempre debe ser considerado cómplice. Ver, por ejemplo, Kristian Kühl, Strafrecht. Allgemeiner Teil, 853 ( $7^{\mathrm{a}}$ ed., Vahlen, München, 2012) y Thomas Weigend, $\S 13$ Begehen durch Unterlassen, en Strafgesetzbuch. Leipziger Kommentar, 815-873, p. 868-869 (12 a ed., De Gruyter Recht, Berlin, 2007). Otros piensan que en estos casos quien omite siempre debe ser considerado autor. Ver, por ejemplo, Uwe Murmann, nota al pie 44, p. 460-463. De acuerdo con una tercera posición, el título de imputación depende del tipo de garante, por ejemplo, el denominado Beschützergarant respondería entonces como autor, mientras que el Überwachungsgarant respondería solo como partícipe. En este sentido ver: Harro Otto, Grundkurs Strafrecht, 296-298 ( $7^{\mathrm{a}}$ ed., De Gruyter Recht, Berlin, 2004); Rolf Dietrich Herzberg, Täterschaft und Teilnahme: eine systematische Darstellung anhand von Grundfällen, 82-99 (C. H. Beck, München, 1977).

102 Günther Jakobs, nota al pie 82, p. 183, 542 (Walter de Gruyter, Berlin, 1983). Para Jakobs, los delitos en los que la responsabilidad penal se fundamenta en la competencia institucional corresponden a delitos de deber, de manera que quien tiene el deber (institucional) de evitar un resultado siempre será autor si no lo cumple y como consecuencia de ello el resultado se produce. La diferencia con el planteamiento de Roxin radica en que para este todos los delitos de omisión impropia constituyen delitos de deber, sin importar el fundamento de la posición de garante, y por esto el garante siempre responde como autor. Claus Roxin, nota al pie 45, p. 671 ss. 
titucional se remite para formular su análisis. De manera que, en casos como este, el miembro de la Fuerza Pública que omite el deber de evitar la violación de derechos de los ciudadanos por parte de terceros y los miembros de un grupo armado ilegal que incurren en conductas equivalentes a crímenes internacionales no necesariamente realizan el mismo injusto, así a los dos se les impute el mismo resultado (de hecho, este constituye un ejemplo de autoría paralela $)^{103}$, puesto que la relación entre ellos no sería de accesoriedad. Claro está, de cumplirse los requisitos, por ejemplo, de la coautoría (lo cual supone un acuerdo común) ${ }^{104}$, las afirmaciones de la Corte en este sentido serían correctas, en la medida en que en estos casos lo determinante es la reciprocidad. Pero también es posible que la omisión del militar sea producto de su negligencia, en cuyo caso su conducta constituiría un tipo penal culposo, de estar contemplado expresamente en la legislación penal colombiana. Es importante recordar entonces que la posición de garante no excluye la posibilidad de la culpa ${ }^{105}$. Claus Roxin, por ejemplo, presenta cuatro situaciones en las que se puede hablar de omisión negligente: (i) cuando el garante ignora la situación de riesgo; (ii) cuando el garante ignora su propia posición de garante respecto a la situación concreta de riesgo; (iii) cuando el garante considera erróneamente que le es imposible actuar; y (iv) cuando el garante realiza la conducta debida pero de forma deficiente ${ }^{106}$. Estos casos se pueden presentar cuando

103 En este sentido, quien comete materialmente el hecho y por lo tanto tiene dominio sobre él es autor, al igual que quien siendo garante no impide la afectación al bien jurídico respectivo; en este caso, el dominio del hecho y la posición de garante son criterios autónomos y equivalentes para efectos de determinar la autoría, de ahí que cada aporte deba ser valorado de forma independiente y las dos personas sean consideradas autores paralelos (Nebentäter), no coautores. Claus Roxin, nota al pie 45, p. 105, 676. Este concepto es relevante para designar aquellos casos en los que varias personas contribuyen sin estar coordinadas en la producción de un resultado. Günther Jakobs, nota al pie 82, p. 539-540.

104 Claus Roxin, nota al pie 45, p. 78-81. Günther Jakobs, nota al pie 82, p. 511. Uwe Murmann, nota al pie 44, p. 339-342.

105 Sobre el delito de omisión (impropia) culposo, Juan Carlos Forero-Ramírez, nota al pie 81, p. 166-171. Fernando Velásquez, nota al pie 81, p. 696. Incluso, la CSJ colombiana ha condenado por delitos culposos por omisión con fundamento en la posición de garante, por ejemplo, con relación al tipo penal de peculado culposo. Corte Suprema de Justicia, Proceso 25536, sentencia de segunda instancia, 27 de julio de 2006, magistrado ponente Álvaro Orlando Pérez-Pinzón.

106 Claus Roxin, nota al pie 45, p. 689-690. Al respecto, Uwe Murmann, nota al pie 44, p. 473-474. Kristian Kühl, nota al pie 101, p. 729-733. 
se trata de miembros de la Fuerza Pública y el riesgo proviene del actuar delictivo de terceros; aquí el miembro de la Fuerza Pública estaría facilitando culposamente el actuar doloso de otra persona y, ciertamente, debido a que tiene posición de garante el resultado le es imputable, pero sin pasar por alto el título de imputación subjetiva que corresponde a $s u$ conducta ${ }^{107}$.

La consecuencia del razonamiento de la Corte Constitucional sería entonces que quien incumple negligentemente su deber responde a título de dolo por el resultado antijurídico causado (dolosamente) por un tercero, debido a que tenía posición de garante. Este resultado deja en entredicho el principio de culpabilidad y reproduce en el ámbito interno las mismas dificultades que en el internacional han sido puestas de manifiesto con relación a la DRSJ, frente a la cual, vale recordar, se han hecho esfuerzos justamente en la dirección contraria. El problema parece estar en que en el CPC no hay modalidad culposa de varios de los tipos penales que equivalen a crímenes internacionales, como la tortura, la desaparición forzada o el desplazamiento forzado (como sí ocurre con el homicidio), y esto constituye un "vacío" difícil de reconocer. Sin embargo, es importante no perder de vista que el hecho de que se trate de violaciones graves de DDHH o de infracciones graves al DIH no puede conducir a formas de responsabilidad objetiva en las que la "atribución subjetiva" no importa. De hecho, es probable que la Corte Constitucional no haya querido sugerir esta conclusión, pues después de haberse referido a este tema, ella misma dice que la responsabilidad penal no surge inmediatamente después de haber sido "verificada la posición de garante", ya que "esta [la responsabilidad penal] presupone la reunión de todos los elementos del delito"108. En todo caso, afirmaciones como las relacionadas con la atribución

107 En este sentido, se debe mencionar la sentencia del 30 de enero de 2012 proferida por la Sala Penal del Tribunal Superior de Bogotá, en la cual se cita la sentencia SU-1184-01 y se precisa que la responsabilidad penal por omisión con base en el artículo $25 \mathrm{CPC}$, cuando el miembro de la Fuerza Pública no tenía conocimiento de los hechos delictivos cometidos pero debía tenerlo ("si no lo supo pero debió saberlo"), debe ser "a título de culpa cuando el delito permita dicha especie de ejecución”. Tribunal Superior de Distrito Judicial de Bogotá, Sala Penal, sentencia del 30 de enero de 2012, apartado 7.3.10.4.

108 Corte Constitucional, nota al pie 83, apartado II. 18. 
subjetiva deberían haber sido desarrolladas más detenidamente para evitar malentendidos, aunque también se podría cuestionar su pertinencia, dado que no todas las consideraciones que realiza la Corte Constitucional con relación a la responsabilidad penal por omisión parecen relevantes en una decisión sobre colisión de competencias.

Las consideraciones que la Corte Constitucional formuló en la sentencia SU-1184-01 y que se acaban de comentar han sido reiteradas en otros pronunciamientos tanto de la misma Corte Constitucional como de la CSJ, sin reparar en sus ambigüedades o contradicciones. En algunos de estos pronunciamientos, esas consideraciones no tocan directamente con el problema jurídico que en ellos se resuelve, pero en todo caso, de esta manera, se hace eco de proposiciones problemáticas que se repiten una y otra vez ${ }^{109}$. Además, en algunas de las decisiones que ha proferido con posterioridad a la SU-1184-01, la CSJ también incurre en otras imprecisiones. Por ejemplo, en la sentencia de casación del 5 de junio de 2014, la cual curiosamente se refiere a los mismos hechos sobre los que se pronunció la Corte Cons-

109 Corte Constitucional, Sentencia T-327-04, 15 de abril de 2004, magistrado ponente Alfredo Beltrán-Sierra. En la sentencia T-327-04, se discutió sobre la procedencia de la acción de tutela con ocasión de las amenazas que el comandante de una brigada del Ejército habría hecho a un civil que se negó a acusar falsamente a otras personas de ser auxiliadoras de la guerrilla y se tomaron medidas para dar cumplimiento a la Resolución del 18 de junio de 2002 de la CorteIDH sobre medidas provisionales solicitadas por la Comisión Interamericana respecto de Colombia (Caso de la Comunidad de Paz de San José de Apartadó). La Corte Constitucional cita en bloque las consideraciones sobre la Fuerza Pública y la posición de garante que aparecen en la sentencia SU-1184-01, para afirmar, sin matices, que el comandante debe asumir "bajo su responsabilidad" la protección de los derechos de las personas a favor de las cuales se interpuso la acción de tutela. También se debe mencionar la sentencia de casación de la CSJ, 14 de noviembre de 2007, mediante la cual se revoca la absolución de algunos policías (entre ellos, un mayor de la Policía Nacional) que habían sido acusados del delito de homicidio, debido a que no impidieron el asesinato de varias personas por parte de un grupo paramilitar, a pesar de que sabían de esta acción ilegal y de que incluso se encontraron con ellos mientras salían del municipio en el cual habían raptado a sus víctimas; en esta misma sentencia se ratificó la condena, también por omisión con fundamento en la posición de garante, de un mayor del Ejército. El debate en esta decisión fue probatorio y la CSJ concluyó que los procesados habían incumplido sus deberes de forma dolosa. CSJ, Sala de Casación Penal, Proceso 28017, sentencia de casación, 14 de noviembre de 2007, magistrado ponente Jorge Enrique Socha-Salamanca. La sentencia de la CSJ en el proceso 24448 constituye otro ejemplo. Aquí, la CSJ condenó como coautor a un teniente del Ejército, quien con su conducta, tanto activa como omisiva, intervino en la perpetración de una masacre cometida por un grupo paramilitar. CSJ, Sala de Casación Penal, Proceso 24448, sentencia de casación, 12 de septiembre de 2007, magistrado ponente Augusto Ibáñez-Guzmán. 
titucional en la sentencia SU-1184-01, la CSJ sostiene que en los delitos de omisión impropia solo cabe la autoría, ya que aquí se aplicaría "un concepto unitario de autor", el cual, según la CSJ, "es acogido por nuestro legislador penal"110. Esto lo explica la CSJ diciendo que "si el sujeto ostenta la posición de garante por tener la obligación jurídica de salvaguardar un bien jurídico y el mismo es lesionado así sea por la acción de un tercero, responde como autor de tal hecho a título de comisión por omisión"l11. Esta última afirmación es correcta en términos generales, pero de ahí no se desprende que en los delitos de omisión impropia se aplique un concepto unitario de autor ni mucho menos que este haya sido acogido por el legislador colombiano ${ }^{112}$. En los delitos de omisión impropia, al ser delitos de deber, tal como lo explica Claus Roxin (a quien la CSJ se refiere en esta parte de la sentencia), el criterio para diferenciar entre autores y partícipes no es el dominio del hecho ${ }^{113}$, como ocurre en los delitos que Roxin denomina de dominio, sino la infracción de un deber ${ }^{114}$. En otras palabras: en los delitos de omisión impropia sigue operando un concepto diferenciado de autor, lo que sucede es que en este contexto el criterio diferenciador varía.

Más adelante, en esta misma decisión se afirma que el superior militar a quien se informa de una amenaza contra la población civil adquiere la posición de garante por el hecho mismo del conocimiento, así no tenga asignada "el área donde ocurre el suceso"115 y que su deber, en caso de no contar con capacidad

110 Ver consideraciones realizadas con relación al segundo cargo (falta de consonancia entre la acusación y la sentencia). CSJ, Sala de Casación Penal, Radicación 35113, sentencia de casación, 5 de junio de 2014, magistrado ponente Eugenio Fernández-Carlier.

111 Ibíd.

112 El CPC acogió, de hecho, un concepto diferenciador de autor y por esto define en el artículo 29 quiénes son autores y en el artículo 30 quiénes son partícipes. En el artículo 25, en el cual se prevé la comisión por omisión y se definen las fuentes de la posición de garante no hay nada que indique que esta diferenciación pierde relevancia en los delitos de omisión impropia. Sobre el concepto de autor en el Código Penal colombiano, Alberto Suárez-Sánchez explica con razón que en Colombia se adoptó un concepto (diferenciador) restrictivo de autor. Alberto Suárez-Sánchez, Autoría, 243-256 (3ª ed., Universidad Externado, Bogotá, 2007).

113 Claus Roxin, nota al pie 45, 106 ss.

114 Ibíd., p. 671.

115 Ver numeral 3 de las consideraciones realizadas con relación al tercer cargo (violación indirecta de la ley sustancial). CSJ, nota al pie 110 . 
de reacción, consistiría en transmitir esa información a quien "sí tenga esa posibilidad de respuesta efectiva" "116, so pena de responder por los crímenes que efectivamente se cometan ${ }^{117}$. En este razonamiento, la CSJ olvida que la posición de garante surge del ámbito de competencia que corresponde al rol social que cumple la persona y que con relación a miembros de la Fuerza Pública esta surge de la competencia que le ha sido previamente asignada en el ordenamiento jurídico vigente. De hecho, por esta razón, la Corte Constitucional había hecho hincapié, con relación a este mismo caso, en que la posición de garante se debe determinar en concreto, teniendo en cuenta el ámbito de competencia material, funcional y territorial de cada individuo. Al decir que la posición de garante se deriva del conocimiento, la CSJ hace depender un elemento objetivo de la responsabilidad penal por omisión de aspectos subjetivos, los cuales se deben establecer en un paso posterior en el análisis de la responsabilidad penal y no son relevantes para determinar si el sujeto tiene o no un deber, sino para establecer la intensidad del injusto en el que se ha incurrido por el incumplimiento de deberes previamente establecidos. Más aún, aquí surge una situación similar a la que ha sido objeto de críticas en el ámbito internacional por lesionar el principio de culpabilidad, según el cual una persona termina siendo responsable a título de omisión por un resultado antijurídico que no podía o no tenía el deber de evitar, con fundamento en el incumplimiento del deber de informar ${ }^{118}$. Las imprecisiones de la CSJ relacionadas con la autoría en los delitos de omisión impropia y con los factores que pueden generar la posición de garante que aquí han sido reseñadas ponen en evidencia nuevamente que la responsabilidad penal por omisión de los miembros de la Fuerza Pública ha representado para la

116 Ibíd.

117 Ibíd.

118 En este caso, si el hecho de no transmitir la información constituye una contribución a la acción que se estaba ejecutando y por lo tanto a la producción del resultado, la responsabilidad penal por la acción de los terceros debería ser a título de complicidad, pero no a título de autoría, ya que, como se ha afirmado, el conocimiento no da lugar a la posición de garante de quien no tiene en su ámbito de competencia el deber de evitar. 
jurisprudencia colombiana un tema complejo frente al cual aún hay dudas importantes.

\author{
IV. LA DOCTRINA DE RESPONSABILIDAD DEL \\ SUPERIOR JERÁRQUICO Y LA RESPONSABILIDAD PENAL \\ POR OMISIÓN EN El CÓDIGo PENAL COLOMBIANO: \\ PUNTOS DE ENCUENTRO Y DIVERGENCIAS
}

Con el fin de contrastar el ámbito de aplicación de la DRSJ con la forma como la responsabilidad penal por omisión está regulada en el CPC, se debe precisar en primer lugar que la DRSJ no corresponde a ninguna de las dos formas generales de omisión desarrolladas por la teoría del delito de procedencia alemana y acogidas en América Latina. La DRSJ no constituye una forma de omisión propia en la medida en que una condición esencial de la responsabilidad del superior es que los subordinados efectivamente hayan cometido un crimen ${ }^{119}$. De manera que, como aquí se ha explicado, la razón de la responsabilidad del superior no es solo el no haber actuado, como ocurre en los delitos de omisión propia, sino el no haber evitado la comisión de un resultado antijurídico, tal como ocurre en los delitos de omisión impropia. Sin embargo, tampoco se trata de una forma de omisión impropia, dado que no se está ante una cláusula general de comisión por omisión o una cláusula general de equivalencia. De hecho, como ya se mencionó, la responsabilidad del superior no necesariamente supone el deber de evitar (y su incumplimiento), pues esta figura también puede tener aplicación cuando se incumple el deber de reprimir o informar sobre crímenes previamente cometidos.

Como se explicó en el apartado II de este trabajo, la DRSJ comprende varias situaciones, unas más problemáticas que otras a la luz del principio de culpabilidad, dependiendo de cuál es el deber que se incumple y de cómo se concreta el elemento subjetivo en cada caso. En consecuencia, el ámbito de aplicación del

119 En este sentido, Thomas Weigend, nota al pie 26, p. 1007. 
artículo 25 CPC no coincide con el de la DRSJ. El artículo 25 CPC, en el cual está regulada la omisión impropia, no cobija las mismas hipótesis fácticas que, por ejemplo, el artículo 28 ECPI. Además, no todas las hipótesis que están contempladas en el artículo 28 ECPI y que también son cubiertas por el artículo 25 CPC conducen en este último ámbito a los mismos resultados que en el DPI. Para explicar mejor este punto, es necesario considerar por separado cada una de las cuatro situaciones mencionadas en el apartado II de este trabajo.

Efectivamente, la situación 1 se puede resolver por medio del artículo 25 CPC. En estos casos, un superior militar no evita la comisión de crímenes por parte de sus subordinados estando en obligación y en capacidad de hacerlo y a pesar de que sabía que esos crímenes se estaban cometiendo o se iban a cometer. Este supuesto puede dar lugar a responsabilidad penal a título de comisión por omisión en la medida en que el superior militar está en posición de garante, conforme al primer párrafo del artículo 25 CPC, debido no solamente a que él debe proteger los derechos de los ciudadanos en general, sino, además, a que él tiene a su cargo "como garante la vigilancia de una determinada fuente de riesgo". Como se ha visto, este constituye el punto de partida de la jurisprudencia colombiana sobre responsabilidad por omisión de miembros de la Fuerza Pública. En estos casos, el superior debe responder a título de dolo por el crimen cometido por sus subordinados y dependiendo de la postura dogmática que se acoja, puede ser responsable como autor o como cómplice. Si se sigue el planteamiento de Günther Jakobs, tal como ha sucedido en la jurisprudencia colombiana, parece más acertado considerar a los miembros de la Fuerza Pública como garantes por competencia institucional (la cual comprende también los deberes que surgen de la competencia por organización), incluso con relación al accionar de los subordinados, y en consecuencia, tratarlos como autores cuando incumplen el deber de evitar que ellos atenten contra la ciudadanía. Aunque tal vez genera menos confusión asumir, con Claus Roxin, que los delitos de omisión impropia constituyen (todos) delitos de infracción de 
deber y que, en consecuencia, el garante responde siempre como autor. De cualquier manera, bajo la lógica de la comisión por omisión, se entendería que el superior también comete el crimen en cuestión al incumplir los deberes que se desprenden de la posición de garante (la omisión se asimila a la consumación). Es posible afirmar entonces que, con relación a este punto, el DPI y el Derecho Penal colombiano en términos generales coinciden. Empero, con las otras tres situaciones no ocurre lo mismo, ya que hay varios aspectos (como las consecuencias que en cada ámbito tienen las distintas formas de atribución subjetiva) que marcan una diferencia importante.

En los casos en los que el superior incumple el deber de evitar, pero de forma negligente, es decir, en los casos de la situación 2 , la consecuencia no puede ser la misma en el ámbito nacional que en el internacional. Si bien este supuesto también se puede subsumir en el artículo $25 \mathrm{CPC}$, el hecho de que el superior no cumpla con el deber de evitar debido, por ejemplo, a la falta negligente de conocimiento sobre los crímenes cometidos por sus subordinados, hace que en el contexto del CPC a este solo se le pueda imputar un delito culposo, siempre que esta forma de responsabilidad haya sido prevista expresamente con relación al tipo penal relevante ${ }^{120}$. Esto es especialmente delicado si se tiene en cuenta, como ya se mencionó, que la mayoría de tipos penales que están previstos en el CPC y que corresponden a crímenes internacionales no tienen modalidad culposa. Evidentemente, los casos de homicidio no serían problemáticos en este sentido $^{121}$, pero no ocurre lo mismo con tipos penales como la tortura, la desaparición forzada, el reclutamiento de menores o el desplazamiento forzado. En el CPC no hay modalidad culposa de estos crímenes, de manera que la omisión negligente del de-

120 Según el artículo 21 CPC: "[...] La culpa y la preterintención solo son punibles en los casos expresamente señalados por la ley".

121 En consecuencia, es posible pensar en casos en que los subordinados responderían por homicidio en persona protegida (artículo 135 CPC) o por homicidio agravado (artículos 103 y 104 $\mathrm{CPC}$ ), mientras que el superior jerárquico que no ha evitado estos crímenes podría responder por homicidio culposo conforme a los artículos 25, 109 y 110 CPC, debido a que su omisión ha sido culposa. De hecho, aquí se estaría ante un caso de autoría paralela. 
ber de evitar no sería punible, de acuerdo con el ordenamiento jurídico penal interno.

Algo similar ocurriría con las situaciones 3 y 4 . El hecho mismo de no reprimir las conductas delictivas en las que incurran los subordinados, teniendo conocimiento, es decir, dolosamente, no está tipificado expresamente en el CPC, lo cual, por lo tanto, podría dar lugar (en principio) únicamente a sanciones disciplinarias. Sin embargo, en estos casos es posible pensar en el tipo penal de prevaricato por omisión. En efecto, el artículo 414 CPC se refiere al "servidor público que omita, retarde, rehúse o deniegue un acto propio de sus funciones". Si se tiene en cuenta que Colombia no solamente es Estado parte ${ }^{122}$ del PA I sino que además, como afirmó la Corte Constitucional al declarar la exequibilidad de este Protocolo, en Colombia "se acogió la fórmula de la incorporación automática del derecho internacional humanitario [...]"123 y en consecuencia "las reglas del derecho internacional humanitario son [...] normas obligatorias per se sin ratificación alguna previa o sin expedición de norma reglamentaria"124, y que la DRSJ tiene carácter consuetudinario y es aplicable en conflictos armados no internacionales, es posible concluir que el deber de reprimir a los subordinados que cometen crímenes internacionales constituye "un acto propio" de las funciones del superior militar en el sentido del artículo 414 CPC de cara al conflicto armado que se vive (¿o vivió?) en este país (esto sin perjuicio de los reglamentos militares existentes) ${ }^{125}$. Incluso, la relevancia de este tipo penal para estos casos se

122 Colombia ratificó el PA I el 1 de septiembre de 1993. Estados parte del PA I y su estado de ratificación, en la página web del Comité Internacional de la Cruz Roja: https://ihl-databases. icrc.org/applic/ihl/ihl.nsf/States.xsp?xp_viewStates=XPages_NORMStatesParties\&xp_treaty Selected=470 (última fecha de acceso 23 de julio de 2016).

123 Corte Constitucional, Sentencia C-574-92, 28 de octubre de 1992, magistrado ponente Ciro Angarita-Barón, apartado V. B. 2. c.

124 Corte Constitucional, Sentencia C-574-92, 28 de octubre de 1992, magistrado ponente Ciro Angarita-Barón, apartado F. Esto fue reiterado con relación al PA II por la Corte Constitucional en la Sentencia C-225-95, 18 de mayo de 1995, magistrado ponente Alejandro MartínezCaballero, apartado II. 5 ss.

125 Esto se refuerza si se tienen en consideración los artículos 21 (deberes del superior) y 23 (mantenimiento de la disciplina) de la Ley 836 de 2003. Colombia, Ley 836 de 2003, por la cual se expide el reglamento del Régimen Disciplinario para las Fuerzas Militares, 45.251 Diario Oficial, 17 de julio de 2003, artículos 21 y 23. 
podría derivar del hecho de que el artículo 415 CPC prevé una pena mayor para el prevaricato cuando la conducta se realiza, entre otros, respecto de los delitos de genocidio, desaparición forzada, tortura, desplazamiento forzado y homicidio. Adicionalmente, se podría tener en cuenta el tipo penal de favorecimiento (artículo 446 CPC), si la omisión del superior militar en estos casos se pudiera interpretar como una forma de ayudar "a eludir la acción de la autoridad o a entorpecer la investigación correspondiente", es decir, como una conducta orientada a ocultar lo sucedido ${ }^{126}$, y si el superior no tuvo conocimiento previo de la conducta delictiva de los subordinados. Este tipo penal también resulta agravado si la conducta se realiza, entre otros, respecto de los delitos de genocidio, desaparición forza$\mathrm{da}$, tortura, desplazamiento forzado u homicidio ${ }^{127}$. La posible aplicación de los tipos penales de prevaricato por omisión y de favorecimiento cuando el superior militar no ha cumplido el deber de sancionar a los subordinados que cometen crímenes internacionales debe ser objeto de una reflexión más profunda ${ }^{128}$. De cualquier manera, el incumplimiento doloso de este deber en sí mismo no caería en el ámbito de aplicación del artículo 25 CPC y debe ser sancionado más bien por medio de un tipo penal de omisión propia. Adicionalmente, ante el incumplimiento del deber de reprimir se debe tener en cuenta si la omisión por parte del superior constituye una forma de alentar o contribuir a la comisión subsiguiente de otros hechos delictivos, en cuyo caso podría hablarse de complicidad con relación al hecho principal

$126 \mathrm{El}$ artículo $446 \mathrm{CPC}$ establece: "El que tenga conocimiento de la comisión de la conducta punible, y sin concierto previo, ayudare a eludir la acción de la autoridad o a entorpecer la investigación correspondiente [...]”.

127 Artículo 446 CPC, parágrafo segundo.

128 Se debe tener en cuenta, por ejemplo, si el hecho de no sancionar a los subordinados que han incurrido en una conducta delictiva equivalente a un crimen internacional afecta al bien jurídico "administración pública" en el sentido de CPC. Sobre la administración pública como bien jurídico tutelado penalmente, Alfonso Gómez-Méndez \& Carlos Arturo Gómez-Pavajeau, Delitos contra la administración pública, 31-73 ( $3^{\mathrm{a}}$ ed., Universidad Externado, Bogotá, 2008). Sobre el tipo penal de prevaricato por omisión, Alfonso Gómez-Méndez \& Carlos Arturo GómezPavajeau, Delitos contra la administración pública, 513 ss. ( $3^{\mathrm{a}}$ ed., Universidad Externado, Bogotá, 2008). Sobre el tipo penal de favorecimiento, Hernando Barreto-Ardila, Delitos contra la eficaz y recta impartición de justicia, en Lecciones de Derecho Penal. Parte Especial, 13-39, p. 28-32 (2a ed., Universidad Externado, Bogotá, 2011). 
de los subordinados ${ }^{129}$, si el superior no tenía posición de garante y no debía evitar el resultado antijurídico (nuevamente: si se parte de la base de que el superior es garante por competencia institucional o si se asume que los delitos de comisión por omisión son delitos de deber, este responde a título de autor). Se debe insistir entonces, en que si esta omisión es culposa, la conducta no es punible, ya que en el CPC no hay algo así como un prevaricato por omisión o un favorecimiento culposos.

Por otro lado, si el superior (no garante) no toma las medidas necesarias para informar a las autoridades competentes sobre crímenes cometidos por los subordinados, estando al tanto de que estos crímenes se cometieron, tampoco habría lugar a aplicar el artículo 25 CPC. En este supuesto entraría en consideración el tipo penal de abuso de autoridad por omisión de denuncia (artículo $417 \mathrm{CPC})^{130}$, el cual, vale decirlo, también es un tipo penal doloso. Al igual que el prevaricato y el favorecimiento, este tipo penal tiene un agravante cuando la omisión de denuncia se da ante delitos especialmente graves ${ }^{131}$. Aunque aquí también se podría considerar el tipo penal de favorecimiento, de darse todos sus elementos, posiblemente en concurso ideal heterogé-

129 Ante esta situación se podría hablar de complicidad psíquica o psicológica, aunque se tendría que establecer el "concierto previo o concomitante", tal como lo exige el artículo $30 \mathrm{CPC}$ al definir la complicidad. Sobre la complicidad psíquica, Claus Roxin, nota al pie 45, p. 198-202. Uwe Murmann, nota al pie 44, p. 364-365. En la literatura colombiana, Fernando Velásquez, nota al pie 81 , p. 923,926 .

130 El primer párrafo del artículo 417 CPC dispone que: "El servidor público que teniendo conocimiento de la comisión de una conducta punible cuya averiguación deba adelantarse de oficio, no dé cuenta a la autoridad, incurrirá en multa y pérdida del empleo o cargo público". Es importante mencionar que el artículo 39 de la Ley Estatutaria 1621 de 2013, en la cual se contempla una excepción para los deberes de denuncia y declaración cuando se trata de servidores públicos que desarrollan actividades de inteligencia y contrainteligencia, excluye de esta excepción los casos de "genocidio, ejecuciones extrajudiciales, tortura, desplazamiento forzado, desaparición forzada, violencia sexual masiva, crímenes de lesa humanidad, o crímenes de guerra por parte de un servidor público". Colombia, Ley Estatutaria 1621 de 2013, por medio de la cual se expiden normas para fortalecer el Marco Jurídico que permite a los organismos que llevan a cabo actividades de inteligencia y contrainteligencia cumplir con su misión constitucional y legal [...], 48.764 Diario Oficial, 17 de abril de 2013.

131 El segundo párrafo del artículo 417 CPC establece que: "La pena será de treinta y dos (32) a setenta y dos (72) meses de prisión si la conducta punible que se omitiere denunciar sea de las contempladas en el delito de omisión de denuncia de particular". El artículo 441 CPC tipifica la “omisión de denuncia de particular" solo cuando se está ante los delitos enunciados de forma taxativa en esa misma norma. 
neo ${ }^{132}$. Sin embargo, si la omisión de denunciar no tiene lugar de forma intencional sino culposa, se estaría nuevamente ante una situación atípica en el ordenamiento jurídico penal interno.

En resumen, es posible afirmar que el DPI y el Derecho Penal nacional únicamente coinciden plenamente en el tratamiento de una de las cuatro situaciones cubiertas por el artículo 28 ECPI aquí identificadas, concretamente con relación a la situación 1. Respecto a las otras tres situaciones hay divergencias importantes. De hecho, no todos los casos que corresponderían a la situación 2 (incumplimiento negligente del deber de evitar) son punibles de acuerdo con el CPC y los que sí lo son no conducen a la misma consecuencia, ya que en este supuesto el superior no puede responder por los mismos crímenes (dolosos) que fueron cometidos por los subordinados, puesto que a él solo se le podrían imputar tipos penales culposos (de estar previstos). Lo mismo ocurre en las situaciones 3 (incumplimiento intencional del deber de reprimir/informar) y 4 (incumplimiento negligente del deber de reprimir/informar). Aquí el ordenamiento jurídico colombiano y el internacional también coinciden solo parcialmente. Respecto a la situación 3 se debe afirmar que la punibilidad del incumplimiento doloso del deber de reprimir no está prevista expresamente en el ordenamiento interno, o al menos no de forma evidente. Sin embargo, a diferencia de lo que ocurre en el ámbito internacional, de aceptarse que esta conducta sí es punible en Colombia, el superior militar no respondería por los crímenes internacionales cometidos por los subordinados sino por los tipos penales de omisión (propia) a que haya lugar (si es el caso de forma agravada). Lo mismo ocurre con el deber de informar o denunciar. En cambio, ni el incumplimiento culposo del deber de reprimir ni el incumplimiento culposo del deber de informar están tipificados en el CPC. Por consiguiente, teniendo en cuenta la anterior comparación, es posible concluir que en el Derecho Penal colombiano, no obstante la jurisprudencia al

132 Sobre el concurso de tipos penales en la legislación penal colombiana, Fernando Velásquez, nota al pie 81 , p. 1014 ss. 
respecto, hay "vacíos" cuando se trata de perseguir penalmente crímenes internacionales. Estos "vacíos" se deben identificar y no se deben perder de vista, ya que al ignorarlos se corre el riesgo de confundir distintas hipótesis fácticas, lo cual puede dar lugar a condenas sin fundamento en el Derecho Penal colombiano vigente. En otras palabras: se debe advertir sobre los límites de nuestro propio Derecho; la remisión indiscriminada al DPI no puede ser una excusa para pasarlos por alto o, peor, para "superarlos" arbitrariamente.

En este punto es pertinente traer a colación, a manera de ejemplo, la forma como en el ordenamiento jurídico alemán ha sido acogida la DRSJ. En Alemania se expidió el 26 de junio de 2002 el Código Penal Internacional o Völkerstrafgesetzbuch (abreviatura en alemán: VStGB), mediante el cual se quiso adaptar el Derecho Penal interno a las exigencias del ECPI ${ }^{133}$. Precisamente, debido a los problemas que la DRSJ presenta a la luz del principio de culpabilidad, aquí se reguló la responsabilidad del superior diferenciando entre distintas hipótesis, con el fin de evitar la imposición de sanciones independientemente de la intensidad o gravedad del injusto ${ }^{134}$. La DRSJ fue contemplada entonces por medio de tres normas diferentes. En el artículo 4 VStGB se tipificó tanto para superiores militares como civiles la omisión dolosa con relación al deber de evitar y se estableció que en estos casos los superiores responderán penalmente como autores por los crímenes cometidos por los subordinados ${ }^{135}$. Por otro lado, en el artículo 13 VStGB se encuentra previsto el

133 Sobre la finalidad y el proceso de expedición del VStGB, Gerhard Werle, Völkerstrafgesetzbuch, en Münchener Kommentar. Strafgesetzbuch. Nebenstrafrecht III, 979-1003, p. 981-983 (Wolfgang Joecks \& Klaus Miebach, eds., C. H. Beck, München, 2013).

134 Gerhard Werle, nota al pie 31, p. 259 ss.

135 El artículo 4 VStGB dispone: "Verantwortlichkeit militärischer Befehlshaber und anderer Vorgesetzter. (1) Ein militärischer Befehlshaber oder ziviler Vorgesetzter, der es unterlässt, seinen Untergebenen daran zu hindern, eine Tat nach diesem Gesetz zu begehen, wird wie ein Täter der von dem Untergebenen begangenen Tat bestraft. § 13 Abs. 2 des Strafgesetzbuches findet in diesem Fall keine Anwendung. (2) Einem militärischen Befehlshaber steht eine Person gleich, die in einer Truppe tatsächliche Befehls- oder Führungsgewalt und Kontrolle ausübt. Einem zivilen Vorgesetzten steht eine Person gleich, die in einer zivilen Organisation oder einem Unternehmen tatsächliche Führungsgewalt und Kontrolle ausübt”. Al respecto, Thomas Weigend, § 4 VStGB, en Münchener Kommentar. Strafgesetzbuch. Nebenstrafrecht III, 1057-1079 ( $2^{\mathrm{a}}$ ed., Wolfgang Joecks \& Klaus Miebach, eds., C. H. Beck, München, 2013). 
incumplimiento del deber de vigilar, según el cual el superior (civil o militar) responde únicamente por el incumplimiento de su deber (no por el delito cometido por los subordinados) y en consecuencia se prevé una pena específica, la cual varía dependiendo de si la omisión es dolosa (pena privativa de la libertad hasta de cinco años) o culposa (pena privativa de la libertad hasta de tres años) ${ }^{136}$. Finalmente, el artículo 14 VStGB consagra el incumplimiento del deber de denunciar como un caso de omisión propia, aunque este supuesto únicamente es punible si se comete con dolo ${ }^{137}$. Estas normas confirman nuevamente que la DRSJ va más allá de la tradicional comisión por omisión reconocida en ordenamientos jurídicos internos como el colombiano (artículo $25 \mathrm{CPC}$ ) o el alemán (artículo $13 \mathrm{StGB}$ ) y que para el juzgamiento de crímenes internacionales en el ámbito nacional ${ }^{138}$ es necesario acudir a tipos penales de omisión propia

136 Por ejemplo, con relación a los superiores militares esta norma, § 13, dispone: "Verletzung der Aufsichtspflicht. (1) Ein militärischer Befehlshaber, der es vorsätzlich oder fahrlässig unterlässt, einen Untergebenen, der seiner Befehlsgewalt oder seiner tatsächlichen Kontrolle untersteht, gehörig zu beaufsichtigen, wird wegen Verletzung der Aufsichtspflicht bestraft, wenn der Untergebene eine Tat nach diesem Gesetz begeht, deren Bevorstehen dem Befehlshaber erkennbar war und die er hätte verhindern können". De acuerdo con Thomas Weigend, este tipo penal constituiría solo en principio un caso de omisión propia, en el que el delito cometido por los subordinados sería una condición objetiva de la punibilidad. En realidad, de acuerdo con este autor, se trataría de un caso de omisión impropia, ya que la punibilidad no se fundamenta únicamente en el no actuar del superior sino en el delito cometido por los subordinados, el cual se debe poder explicar por la falta de vigilancia y debe haber sido previsible. Al respecto, Thomas Weigend, § 13-§14 VStGB, en Münchener Kommentar. Strafgesetzbuch. Nebenstrafrecht III, 1367-1383, p. 1368 (2 ed., Wolfgang Joecks \& Klaus Miebach, eds., C. H. Beck, München, 2013).

137 Según el artículo 14 VStGB: "Unterlassen der Meldung einer Straftat (1) Ein militärischer Befehlshaber oder ein ziviler Vorgesetzter, der es unterlässt, eine Tat nach diesem Gesetz, die ein Untergebener begangen hat, unverzüglich der für die Untersuchung oder Verfolgung solcher Taten zuständigen Stelle zur Kenntnis zu bringen, wird mit Freiheitsstrafe bis zu fünf Jahren bestraft". Este es un tipo penal de omisión propia en el que la peligrosidad (en abstracto) de la conducta con miras a la posible comisión futura de crímenes previstos en el VStGB es suficiente. Thomas Weigend, nota al pie 136, p. 1378.

138 Como ejemplo también se puede mencionar el Crimes Against Humanity and War Crimes Act de Canadá, adoptado el 29 de junio del año 2000. Aquí, también con el fin de solventar los problemas que de la DRSJ surgen a la luz del principio de culpabilidad, en las secciones 5 y 7 se estableció como un crimen autónomo el incumplimiento de los deberes del superior. En estos casos, el superior no responde por los crímenes concretos cometidos por sus subordinados sino por un delito de omisión independiente: "breach of responsibility by military commander" o "breach of responsibility by a superior", dependiendo de si el superior es militar o civil. Al respecto, Kimberly Prost \& Darryl Robinson, Canada, en The Rome Statute and Domestic Legal Orders, Volume II: Constitutional Issues, Cooperation and Enforcement, 53-69, p. 54-55 (Claus Kreß, Bruce Broomhall, Flavia Lattanzi \& Valeria Santori, eds., Nomos, Baden-Baden, 2005). 
específicos con el fin de cubrir las distintas hipótesis que en el ámbito internacional pueden dan lugar a la responsabilidad del superior jerárquico ${ }^{139}$.

\section{OBSERVACIONES FINALES: EN ESPECIAL CON RELACIÓN A LA RESPONSABILIDAD DEL SUPERIOR JERÁRQUICO Y LA JURISDICCIÓN ESPECIAL PARA LA PAZ}

Como se ha visto en este trabajo, la DRSJ es una forma de responsabilidad por omisión que ha sido desarrollada en el derecho internacional y que abarca varias situaciones en las que son relevantes distintos tipos de deberes. De hecho, la DRSJ no hace referencia únicamente a una forma de intervención en un hecho delictivo perpetrado materialmente por terceros sino también a supuestos que en sí mismos pueden ser considerados como delitos de forma autónoma. La DRSJ constituye entonces una figura que, por decirlo de alguna manera, se encuentra entre lo que comúnmente se conoce como parte general y parte especial del Derecho Penal, de ahí su carácter sui generis y las dificultades que ha generado su aplicación. Esta es una de las razones por las que la DRSJ ha sido cuestionada, pues de no diferenciarse las distintas hipótesis que ella abarca, es fácil pasar por alto que no todos los casos en los que ella puede aplicarse ostentan la misma gravedad. Por esta misma razón, es importante evitar las referencias indiscriminadas al DPI cuando en el ámbito nacional se habla de responsabilidad penal por omisión de mandos militares, y es recomendable no perder de vista cuál debe ser el tratamiento que de acuerdo con la legislación penal colombiana corresponde a cada caso en concreto.

Con base en lo anterior, es posible realizar algunas observaciones finales respecto a las referencias que en los últimos años

139 En este sentido, es importante recordar la afirmación de Cryer, Friman, Robinson y Wilmshurst: "command responsibility is un-nuanced, covering many different forms of liability under one heading. It moves from deliberate failure to intervene despite a duty to do so, which fall close to traditional complicity ideas, to, in essence, conduct which is close to, if not the same as, negligent dereliction of duty". Robert Cryer y otros, nota al pie 26, p. 395. 
se han hecho en Colombia a la DRSJ. Con relación a la idea de responsabilidad del superior como criterio para establecer quiénes son los máximos responsables, según lo estableció la Corte Constitucional en la sentencia C-579-13 sobre el MJP'140, se debe señalar que, precisamente con el fin de determinar quiénes son los máximos responsables, no es suficiente remitirse de forma genérica a esta figura, pues, como aquí se ha mostrado, esta forma de responsabilidad abarca diferentes situaciones y no todas tienen la misma gravedad. De manera que vale la pena preguntarse, por ejemplo, si los casos de incumplimiento negligente del deber de evitar por parte del superior militar son lo suficientemente graves como para ser seleccionados con miras a un proceso penal en el marco de mecanismos judiciales de justicia transicional (de hecho, se debe determinar en primer lugar si la conducta es realmente típica de acuerdo con el CPC). Lo mismo ocurre con el incumplimiento del deber de reprimir o de denunciar. Como se ha visto, no en todos los casos es posible imputar al superior el crimen cometido por los subordinados e incluso, cuando la omisión se debe a la negligencia del superior, la conducta puede ser atípica. Así, si se tiene en cuenta que según la Corte Constitucional, máximo responsable puede ser "tanto el jefe de un grupo, como también quien haya tenido un rol esencial en la comisión de los crímenes de acuerdo al papel que la persona pudiese jugar dentro de la organización"141, es

140 Se debe advertir que, por el momento, la relación entre el MJP y la JEP que se diseñó en el acuerdo sobre víctimas no es del todo clara. Entre otras cosas, el MJP dispone que el Congreso de la República puede establecer mediante ley estatutaria criterios de selección para que la Fiscalía General de la Nación pueda concentrar sus esfuerzos en la investigación de los máximos responsables de los crímenes más graves, básicamente crímenes internacionales. Asimismo, mediante el MJP se autorizó al Fiscal General de la Nación para que adopte criterios de priorización para el ejercicio de la acción penal. Por otro lado, en el acuerdo sobre víctimas se estableció que en el contexto de la JEP la investigación y la acusación ante el Tribunal de Paz estará a cargo de una Unidad especial de investigación y acusación, no de la Fiscalía General de la Nación (ver punto 46 y 51 del acuerdo). En todo caso, en varios puntos del acuerdo se habla o se sugiere la selección y priorización de casos con relación a varios de los órganos que allí se diseñaron, como por ejemplo en los puntos 20, 48 (o), 50 (c) y en el punto 51 (d). Así pues, al parecer, por ejemplo, no será necesario que el Congreso de la República sean quien determine los criterios de selección cuando se trate de crímenes de competencia de la JEP. Pero, de cualquier manera, las consideraciones que la Corte Constitucional hizo al respecto en la sentencia C-579 de 2013 son igualmente relevantes en este contexto.

141 Corte Constitucional, nota al pie 1, apartado 8.2.3. 
posible afirmar que no siempre que la DRSJ pueda ser aplicada a un caso particular, se estará ante una de las situaciones más graves y tal vez ni siquiera ante un máximo responsable en los términos en que este concepto ha sido definido por la Corte, pues a pesar de haber tenido algún tipo de mando y de haber incumplido uno o varios de sus deberes, un militar puede tener una participación "accesoria" o más o menos marginal frente a la conducta de los subordinados; en otras palabras: no siempre que es aplicable la DRSJ se está necesariamente ante un superior que ha cumplido "un rol esencial" en la comisión de un crimen internacional por parte de sus subalternos. Claro está, la determinación de la gravedad de una conducta para efectos de seleccionar un caso supone una valoración político criminal, pero esta no puede pasar por alto los matices que hay tanto en el Derecho Penal nacional como en el internacional.

Por otro lado, se debe decir que la frase "en ningún caso la responsabilidad del mando podrá fundarse exclusivamente en el rango, la jerarquía o el ámbito de jurisdicción", la cual aparece en los puntos 44 y 59 del acápite sobre la JEP del acuerdo al que llegaron el gobierno colombiano y las FARC y que se encontraba en el proyecto de ley estatutaria 268 (Cámara) y 211 (Senado) de 2013 (ver apartado I de este trabajo), no supone nada nuevo. En términos generales, esta disposición ni agrega ni modifica nada frente al Derecho Penal vigente en Colombia o frente al DPI. Si la responsabilidad penal se fundara exclusivamente en la posición de mando, claramente se estaría violando el principio de culpabilidad. Esta afirmación parece obedecer más a posibles temores de miembros de la Fuerza Pública colombiana o de las FARC, producto de la desconfianza ante el Tribunal para la Paz que deberá crearse como consecuencia del acuerdo final, que a una evaluación concienzuda de la legislación penal vigente en el país. En todo caso, por esto es importante evitar ambigüedades como en las que han incurrido la Corte Constitucional o la CSJ y que han sido señaladas en este trabajo. En la JEP se debe evitar la impresión de que las condenas se imponen de forma arbitraria, pues en medio están la legitimidad de las decisiones 
judiciales frente a los ciudadanos en general - e incluso frente a las mismas partes del conflicto (que han acordado cesar las hostilidades) — y la legitimidad del proceso de paz como tal.

Lo mismo ocurre con varios de los elementos que se mencionan en ese acuerdo, como por ejemplo: control efectivo, conocimiento y medios a disposición para prevenir. Estos tres elementos deben ser considerados tanto en aplicación del artículo 25 del CPC (así no se mencionen expresamente) como en el contexto de la CPI. Sin embargo, un aspecto sobre el cual sí podría haber discusión es el del conocimiento, ya que con base en lo dispuesto en el acuerdo sobre víctimas (el acuerdo dice: "conocimiento basado en la información a su disposición antes, durante y después"), es posible preguntarse si solamente podrá haber responsabilidad penal por omisión de los mandos militares cuando el superior efectivamente haya contado con información a su disposición o si se aceptará que el superior también tiene un deber de conocer, el cual puede ser infringido de forma negligente. Se debe recordar, sin embargo, que la responsabilidad penal a título de omisión por negligencia también puede darse cuando el garante considera erróneamente que le es imposible actuar o cuando realiza la conducta debida pero de forma deficiente. En consecuencia, el hecho de que haya existido algún tipo de información a disposición del superior no necesariamente significa que este haya actuado dolosamente.

Adicionalmente, es importante advertir que se deben evitar confusiones con la expresión "control efectivo de la respectiva conducta", la cual se encuentra en el acuerdo de paz, puntos 44 y 59 del acápite sobre la JEP. Esta expresión podría entenderse (equivocadamente) como dominio sobre los hechos. Sin embargo, como aquí se explicó, la DRSJ alude a formas de responsabilidad por omisión y por esto es imposible que en estos supuestos el superior (penalmente responsable) haya tenido el control efectivo sobre los crímenes cometidos por los subordinados. De entenderse de esta manera, se estaría desfigurando la responsabilidad del superior tal y como se ha definido en el Derecho Internacional. De ahí que, en este contexto la discusión 
no deba ser si el superior controlaba los hechos, lo cual constituye un elemento de la responsabilidad penal por acción a título de autor, sino la existencia de un deber, su incumplimiento y si el superior estaba en posibilidad de cumplirlo. De hecho, posiblemente con el fin de evitar esta confusión, en la versión del acuerdo final del 12 de noviembre de 2016 se incluyó el párrafo que conecta la expresión "control efectivo de la respectiva conducta" con "la posibilidad real que el superior tenía de haber ejercido un control apropiado sobre sus subalternos", lo cual extrañamente se eliminó del punto 44 en la versión del acuerdo final publicada el 24 de noviembre de 2016.

En cualquier caso, se debe recordar que el artículo $25 \mathrm{CPC}$ exige, para que haya responsabilidad penal a título de comisión por omisión, que el garante haya estado en posibilidad de evitar el resultado, lo cual en estos supuestos supone control efectivo por parte del superior sobre los subordinados y que el superior haya tenido los medios necesarios para cumplir sus deberes. De hecho, por esta misma razón, como lo afirmó la Corte Constitucional en el sentencia SU-1184-01 y se mencionó en el apartado III de este trabajo, la responsabilidad penal no surge inmediatamente después de hacer sido "verificada la posición de garante", ya que "esta presupone la reunión de todos los elementos del delito".

Para terminar, es posible preguntarse si los puntos que en el acuerdo de paz hacen referencia a la DRSJ llevarán a que cuando se implemente y/o reglamente la JEP se adopte alguna norma sustantiva específica sobre este tema. Esto no es del todo claro $^{142}$. Si no se hace, los casos de omisión de superiores militares deberán ser tratados conforme a las normas penales internas vigentes al momento en que se cometieron los hechos, teniendo en cuenta,

142 En el acuerdo de paz (versión del 12 de noviembre de 2016, p. 147), en el punto 19 del acápite sobre la JEP, se afirma de manera un tanto ambigua, que los órganos que se deben crear como parte de esta jurisdicciónn: "harán una calificación jurídica propia del Sistema respecto a las conductas objeto del mismo, calificación que se basará en el Código Penal colombiano y/o en las normas de Derecho Internacional en materia de Derechos Humanos (DIDH), Derecho Internacional Humanitario (DIH) o Derecho Penal Internacional (DPI), siempre con aplicación del principio de favorabilidad". 
claro está, sus requisitos y límites, de acuerdo con las precisiones que se han hecho en los apartados III y IV de este trabajo (por ejemplo con relación al artículo 25 del CPC). Empero, de expedirse una nueva norma o conjunto de normas sobre la materia, no se puede pasar por alto que de acogerse alguna de las definiciones que se pueden encontrar en el ámbito internacional, no se estaría adoptando solamente una medida relacionada con la forma de imputación de los tipos penales que ya existen en el CPC, sino que además se pueden estar tipificando conductas hasta ahora no punibles (por ejemplo con relación a los deberes de sancionar o informar) o se pueden modificar las consecuencias que cierto tipo de conductas tienen actualmente según la legislación penal colombiana (por ejemplo cuando la omisión es negligente). Por esta razón, en cualquier decisión que se tome en este sentido se deben tener en cuenta los problemas que eventualmente pueden surgir frente al principio de legalidad, concretamente, por la eventual aplicación retroactiva de la nueva norma (esto, claro está, exige un estudio detallado aparte). En todo caso, el tratamiento de este tema en el ámbito interno debe obedecer a parámetros unificados, sin importar si se trata de agentes del Estado o de integrantes de las FARC. Esto es una exigencia básica del principio de igualdad y se desprende también del DPI, en donde la condición jurídica de las partes de un conflicto armado no es un factor relevante. Así pues, el hecho de que con relación a los integrantes de las FARC se haya hecho referencia al Derecho Internacional (última versión del punto 59) para definir el elemento "control efectivo de la respectiva conducta", mientras que con relación a los miembros de la Fuerza Pública dicha aclaración se haya eliminado del punto 44, no debe conducir a un tratamiento desigual. Por lo demás, se debe resaltar que las discusiones que se han dado en torno a la jurisprudencia de los tribunales penales internacionales, en especial con miras al principio de culpabilidad, así como la forma (diferenciada) en que la DRSJ ha sido implementada en algunos países para cumplir justamente con este principio, pueden y deben tomarse como insumo en el contexto colombiano, con el fin de aprender de la experiencia comparada. 


\section{BIBLIOGRAFÍA}

\section{Libros}

Ambos, Kai, Der Allgemeine Teil des Völkerstrafrechts. Ansätze einer Dogmatisierung ( $2^{\text {a }}$ ed., Duncker \& Humblot, Berlin, 2004).

Ambos, Kai, Treatise on International Criminal Law, Volume I (Oxford University Press, Oxford, 2014).

American Law Institute, ALI, Model Penal Code and Commentaries, Part I (The American Law Institute, ALI, Philadelphia, 1985).

Ashworth, Andrew \& Horder, Jeremy, Principles of Criminal Law ( $7^{\text {th }}$ ed., Oxford University Press, Oxford, 2013).

Baker, Dennis J., Glanville Williams Textbook of Criminal Law ( $3^{\mathrm{a}}$ ed., Sweet \& Maxwell, London, 2012).

Bantekas, Ilias, International Criminal Law (4 ed., Hart Publishing, Oxford, Portland, 2010).

Cassese, Antonio, Cassese's International Criminal Law (3 ${ }^{\mathrm{a}}$. ed., Oxford University Press, Oxford, 2013).

Cryer, Robert; Friman, Håkan; Robinson, Darryl \& Wilmshurst, Elizabeth, An Introduction to International Criminal Law and Procedure ( $3^{\mathrm{a}}$ ed., Cambridge University Press, Cambridge, 2014).

Forero-Ramírez, Juan Carlos, El delito de omisión en el nuevo Código Penal (Legis, Bogotá, 2002).

Fuchs-Kaninski, Denise, Der Beitrag des Sondergerichtshofs für Sierra Leone zum Völkerstrafrecht (Optimus Verlag, Göttingen, 2015).

Garner, Bryan A. (editor in chief), Black's Law Dictionary $\left(10^{\text {th }}\right.$ ed., Thomson Reuters, Saint Paul, Minnesota, 2014).

Gómez-Méndez, Alfonso \& Gómez-Pavajeau, Carlos Arturo, Delitos contra la administración pública ( $3^{\mathrm{a}}$ ed., Universidad Externado, Bogotá, 2008).

Henckaerts, Jean-Marie \& Doswald-Beck, Louise, Customary International Law, Volume I: Rules (Cambridge University Press, Cambridge, 2005). Disponible en: https://www.icrc.org/eng/assets/files/other/customary-international-humanitarianlaw-i-icrc-eng.pdf

Herzberg, Rolf Dietrich, Täterschaft und Teilnahme: eine systematische Darstellung anhand von Grundfällen (C. H. Beck, München, 1977).

Jakobs, Günther, Strafrecht. Allgemeiner Teil: die Grundlagen und die Zurechnungslehre Lehrbuch (Walter de Gruyter, Berlin, 1983).

Kaufmann, Arthur, Das Schuldprinzip. Eine strafrechtlich-rechtsphilosophische Untersuchung ( $2^{\text {nd }}$ ed., Carl Winter Universitätsverlag, Heidelberg, 1976).

Kühl, Kristian, Strafrecht. Allgemeiner Teil (7 ed., Vahlen, München, 2012).

Murmann, Uwe, Grundkurs Strafrecht (3 ${ }^{\mathrm{a}}$ ed., C. H. Beck, München, 2015).

Otto, Harro, Grundkurs Strafrecht ( $7^{\mathrm{a}}$ ed., De Gruyter Recht, Berlin, 2004). 
Pilloud, Claude; Preux, Jean de; Zimmermann, Bruno; Eberlin, Philippe; Gasser, HansPeter \& Wenger, Claude, Protocol I, en Commentary on the Additional Protocols of 8 June 1977 to the Geneva Conventions of 12 August 1949 (Jean Pictet, Chairman, Martinus Nijhoff Publishers, Geneva, 1987). Disponible en: http://www.loc.gov/ rr/frd/Military_Law/pdf/Commentary_GC_Protocols.pdf

Roxin, Claus, Strafrecht. Allgemeiner Teil, Band II: Besondere Erscheinungsformen der Straftat (C. H. Beck, München, 2003).

Suárez-Sánchez, Alberto, Autoría ( $3^{\mathrm{a}}$ ed., Universidad Externado, Bogotá, 2007).

Velásquez-Velásquez, Fernando, Derecho penal. Parte general ( $4^{\mathrm{a}}$ ed., Comlibros, Medellín, 2009).

Werle, Gerhard, Völkerstrafrecht ( $3^{\mathrm{a}}$ ed., Mohr Siebeck, Tübingen, 2012).

Wessels, Johannes; Beulke, Werner \& Satzger, Helmut, Strafrecht. Allgemeiner Teil (45 a ed., C. F. Müller, Heidelberg, 2015).

\section{Contribuciones en obras colectivas}

Aponte-Cardona, Alejandro, Superior jerárquico, omisión impropia y posiciones de garantía: tensiones actuales entre dogmática y jurisprudencia, en Derecho Penal y Crítica al Poder Punitivo del Estado, Tomo 2, 1079-1111 (Fernando Velásquez, Ricardo Posada, Alfonso Cadavid, Ricardo Molina \& Juan Oberto Sotomayor, eds., Grupo Editorial Ibáñez, Bogotá, 2013).

Barreto-Ardila, Hernando, Delitos contra la eficaz y recta impartición de justicia, en Lecciones de Derecho Penal. Parte Especial, 13-39 (2 ${ }^{\text {a }}$ ed., Universidad Externado, Bogotá, 2011).

Cote-Barco, Gustavo Emilio \& Tarapués-Sandino, Diego Fernando, El Marco Jurídico para la Paz y el análisis estricto de sustitución de la Constitución realizado en la Sentencia C-579 de 2013, en Justicia de Transición y Constitución, 197-271 (Kai Ambos, coord., Temis, Bogotá, 2014). Disponible en: http://www.kas.de/rspla/es/ publications/37903/

Hopkins, Russell, The Case 002/01 Trial Judgment: A Stepping Stone from Nuremberg to the Present?, en The Extraordinary Chambers in the Courts of Cambodia. Assessing their Contribution to International Criminal Law, 181-201 (Simon M. Meisenberg \& Ignaz Stegmiller, ed., Springer, Berlin, Heidelberg, 2016).

Prost, Kimberly \& Robinson, Darryl, Canada, en The Rome Statute and Domestic Legal Orders, Volume II: Constitutional Issues, Cooperation and Enforcement, 53-69 (Claus Kreß, Bruce Broomhall, Flavia Lattanzi \& Valeria Santori, eds., Nomos, Baden-Baden, 2005).

Triffterer, Otto \& Arnold, Roberta, Article 28. Responsibility of Commanders and Other Superiors, en The Rome Statute of the International Criminal Court. A Commentary, 1056-1106 ( $3^{\text {a }}$ ed., Otto Triffterer \& Kai Ambos, ed., C. H. Beck, Hart, Nomos, München, 2016).

Werle, Gerhard, Völkerstrafgesetzbuch, en Münchener Kommentar. Strafgesetzbuch. Nebenstrafrecht III, 979-1003 (Wolfgang Joecks \& Klaus Miebach, eds., C. H. 
Beck, München, 2013).

Weigend, Thomas, § 4 VStGB, en Münchener Kommentar. Strafgesetzbuch. Nebenstrafrecht III, 1057-1079 (2a ed., Wolfgang Joecks \& Klaus Miebach, eds., C. H. Beck, München, 2013).

Weigend, Thomas, $\S 13$ Begehen durch Unterlassen, en Strafgesetzbuch. Leipziger Kommentar, 815-873 (12 a ed., De Gruyter Recht, Berlin, 2007).

Weigend, Thomas, $\S 13-\S 14$ VStGB, en Münchener Kommentar. Strafgesetzbuch. Nebenstrafrecht III, 1367-1383 (2 ${ }^{\text {a }}$ ed., Wolfgang Joecks \& Klaus Miebach, eds., C. H. Beck, München, 2013).

\section{Revistas}

Damaška, Mirjan R., The Shadow Side of Command Responsibility, 49 American Journal of Comparative Law, 455-496 (2001). Disponible en: http://digitalcommons.law. yale.edu/cgi/viewcontent.cgi? article $=2598 \&$ context $=$ fss_papers

George P. Fletcher \& Jens David Ohlin, Reclaiming Fundamental Principles of Criminal Law in the Darfur Case, 3 Journal of International Criminal Justice, JICJ, 539-561 (2005). Disponible en: http://scholarship.law.cornell.edu/cgi/viewcontent. cgi? article $=1497 \&$ context $=$ facpub

Martínez, Jenny S., Understanding Mens Rea in Command Responsibility. From Yamashita to Blaškić and beyond, 5 Journal of International Criminal Justice, JICJ, 638-664 (2007).

Meloni, Chantal, Command Responsibility. Mode of Liability for the Crimes of Subordinates or Separate Offence of the Superior?, 5 Journal of International Criminal Justice, 619-637 (2007).

Robinson, Darryl, How Command Responsibility got so Complicated: A Culpability Contradiction, its Obfuscation, and a Simple Solution, 13 Melbourne Journal of International Law, 1-58 (2012). Disponible en: http://law.unimelb.edu.au/_data/ assets/pdf_file/0003/1687242/Robinson.pdf

Triffterer, Otto, Causality, a Separate Element of the Doctrine of Superior Responsibility as Expressed in Article 28 Rome Statute?, 15 Leiden Journal of International Law, 1, 179-205 (2002).

Weigend, Thomas, Bemerkungen zur Vorgesetztenverantwortlichkeit im Völkerstrafrecht, 116 Zeitschrift für die gesamte Strafrechtswissenschaft, 4, 999-1027 (2004).

\section{Tratados internacionales}

Agreement between the United Nations and the Government of Sierra Leone and Statute of the Special Court for Sierra Leone, 16 January 2002. Disponible en: https:// ihl-databases.icrc.org/ihl/INTRO/605?OpenDocument

Convención relativa a las leyes y usos de la guerra terrestre y reglamento anexo (H.II), La Haya, 29 de julio de 1899. Disponible en: http:/www.cruzroja.es/dih/pdf/ II_convenio_de_la_haya_de_1899_relativa_a_leyes_usos_guerra_terrestre_y_ 
reglamento_anexo.pdf

Convención relativa a las leyes y costumbres de la guerra terrestre (H.IV), La Haya, 18 de octubre de 1907. Disponible en: https://www.icrc.org/spa/resources/documents/ misc/treaty-1907-hague-convention-4-5tdm34.htm

Convenio de Ginebra I, para aliviar la suerte que corren los heridos y los enfermos de las fuerzas armadas en campaña, Ginebra, 12 de agosto de 1949. Disponible en: https://www.icrc.org/spa/assets/files/publications/convenios-gva-esp-2012.pdf

Convenio de Ginebra II, para aliviar la suerte que corren los heridos, los enfermos y los náufragos de las fuerzas armadas en el mar, Ginebra, 12 de agosto de 1949. Disponible en: https://www.icrc.org/spa/assets/files/publications/convenios-gvaesp-2012.pdf

Convenio de Ginebra III, relativo al trato debido a los prisioneros de guerra, Ginebra, 12 de agosto de 1949. Disponible en: https://www.icrc.org/spa/assets/files/publications/ convenios-gva-esp-2012.pdf

Convenio de Ginebra IV, relativo a la protección debida a las personas civiles en tiempo de guerra, Ginebra, 12 de agosto de 1949. Disponible en: https://www.icrc.org/spa/ assets/files/publications/convenios-gva-esp-2012.pdf

Estatuto de la Corte Penal Internacional, ECPI, o Estatuto de Roma, A/CONF.183/9, Roma, 17 de julio de 1998, enmendado por los procès verbaux de 10 de noviembre de 1998, 12 de julio de 1999, 30 de noviembre de 1999, 8 de mayo de 2000, 17 de enero de 2001 y 16 de enero de 2002. En vigor desde el 1 de julio de 2002. Disponible en: http://www.un.org/spanish/law/icc/statute/spanish/rome_statute(s).pdf

Protocolo I adicional a los Convenios de Ginebra de 1949 relativo a la protección de las víctimas de los conflictos armados internacionales, 8 de junio de 1977. Disponible en: https://www.icrc.org/spa/resources/documents/misc/protocolo-i.htm

\section{Resoluciones del Consejo de Seguridad de Naciones Unidas}

Estatuto del Tribunal Internacional para juzgar a los presuntos responsables de graves violaciones del derecho internacional humanitario cometidas en el territorio de la ex Yugoslavia a partir de 1991, Estatuto Internacional adoptado por el Consejo de Seguridad, Resolución 827, 25 de mayo de 1993. Disponible en: https://www.icrc. org/spa/resources/documents/misc/treaty-1993-statute-tribunal-former-yugoslavia5tdm74.htm

Estatuto del Tribunal Internacional para Rwanda, 8 de noviembre de 1994, Resolución 955 del Consejo de Seguridad de las Naciones Unidas, S/RES/955 (1994). Disponible en: https://www.icrc.org/spa/resources/documents/misc/treaty-1994-statutetribunal-rwanda-5tdmhw.htm

\section{Normatividad Extranjera}

Allied Control Council, Law No. 10, Punishment of Persons Guilty of War Crimes, Crimes against Peace and against Humanity, Berlin, 20 December 1945. Disponible 
en: http://avalon.law.yale.edu/imt/imt10.asp

Alemania, Código Penal, German Criminal Code, Strafgesetzbuch, StGB, 15 May 1871. Disponible en: http://www.gesetze-im-internet.de/stgb/, http://www.gesetze-iminternet.de/englisch_stgb/index.html

Alemania, Código Penal Internacional, Code of Crimes against International Law, Völkerstrafgesetzbuch, VStGB, 26 June 2002. Disponible en: https://www.gesetzeim-internet.de/vstgb/BJNR225410002.html, https://www.mpicc.de/files/pdf1/ vstgbleng2.pdf

Canadá, Crimes against Humanity and War Crimes Act, S.C. 2000, c. 24, assented to 29 June 2000. Disponible en: http://laws-lois.justice.gc.ca/eng/acts/c-45.9/

\section{Normatividad colombiana}

Colombia, Acto Legislativo 1 de 2012, por medio del cual se establecen instrumentos jurídicos de justicia transicional en el marco del artículo 22 de la Constitución Política y se dictan otras disposiciones, 48.058 Diario Oficial, 31 de julio de 2012. Disponible en: http://wsp.presidencia.gov.co/Normativa/actos-legislativos/Documents/2012/ACTO\%20LEGISLATIVO $\% 20 \mathrm{~N} \% \mathrm{C} 2 \% \mathrm{~B} 0 \% 2001 \% 20 \mathrm{DEL} \% 2031 \% 20$ DE\%20JULIO\%20DE\%202012.pdf

Colombia, Acto Legislativo 2 de 2012, por el cual se reforman los artículos 116, 152 y 221 de la Constitución Política de Colombia, 48.657 Diario Oficial, 28 de diciembre de 2012. Disponible en: http://wsp.presidencia.gov.co/Normativa/actos-legislativos/ Documents/2012/ACTO\%20LEGISLATIVO\%20N\%C2\%B0\%2002\%20DEL\%20 27\%20DE\%20DICIEMBRE\%20DE\%202012.pdf

Colombia, Acto Legislativo 1 de 2015, por el cual se reforma el artículo 221 de la Constitución Política de Colombia, 49.554 Diario Oficial, 25 de junio de 2015. Disponible en: http://www.secretariasenado.gov.co/senado/basedoc/acto_legislativo_01_2015.html

Colombia, Constitución Política, versión corregida, 116 Gaceta Constitucional, 20 de julio de 1991. Disponible en: http://www.secretariasenado.gov.co/index.php/ constitucion-politica

Colombia, Ley 599 de 2000, por la cual se expide el Código Penal, 44.097 Diario Oficial, 24 de julio de 2000. Disponible en: http://www.secretariasenado.gov.co/ senado/basedoc/ley_0599_2000.html

Colombia, Ley 836 de 2003, por la cual se expide el reglamento del Régimen Disciplinario para las Fuerzas Militares, 45.251 Diario Oficial, 17 de julio de 2003. Disponible en: http://www.secretariasenado.gov.co/senado/basedoc/ley_0836_2003.html

Colombia, Ley 1407 de 2010, por la cual se expide el Código Penal Militar, 47.804 Diario Oficial, 17 de agosto de 2010. Disponible en: http://www.secretariasenado. gov.co/senado/basedoc/ley_1407_2010.html

Colombia, Ley 1765 de 2015, por la cual se reestructura la Justicia Penal Militar y Policial, se establecen requisitos para el desempeño de sus cargos, se implementa su Fiscalía General Penal Militar y Policial, se organiza su cuerpo técnico de investigación, se señalan disposiciones sobre competencia para el tránsito al 
sistema penal acusatorio y para garantizar su plena operatividad en la Jurisdicción Especializada y se dictan otras disposiciones, 49.582 Diario Oficial, 23 de julio de 2015. Disponible en: http://www.secretariasenado.gov.co/senado/basedoc/ ley_1765_2015_pr002.html

Colombia, Ley Estatutaria 1621 de 2013, por medio de la cual se expiden normas para fortalecer el Marco Jurídico que permite a los organismos que llevan a cabo actividades de inteligencia y contrainteligencia cumplir con su misión constitucional y legal, y se dictan otras disposiciones, 48.764 Diario Oficial, 17 de abril de 2013. Disponible en: http://www.secretariasenado.gov.co/senado/basedoc/ley_1621_2013. html

\section{Proyectos de ley}

Colombia, Proyecto de ley estatutaria 268 (Cámara), 211 de 2013 (Senado), por la cual se desarrollan los artículos 116 y 221 de la Constitución Política de Colombia y se dictan otras disposiciones, ponencia para primer debate en Comisiones Primeras Conjuntas, 350 Gaceta del Congreso, 22 de mayo de 2013. Disponible en: http://www.imprenta.gov.co/gacetap/gaceta.mostrar_documento?p_tipo $=18 \& \mathrm{p}$ numero $=211 \& p \_$consec $=35672$, http://www.imprenta.gov.co/gacetap/gaceta.nivel_ 3

\section{Jurisprudencia de Tribunales internacionales}

Corte Interamericana de Derechos Humanos, CorteIDH, Resolución de la Corte Interamericana, sobre las Medidas Provisionales solicitadas por la Comisión Interamericana respecto de Colombia, Caso de la Comunidad de Paz de San José de Apartadó, 18 de junio de 2002. Disponible en: http://www.corteidh.or.cr/docs/ medidas/apartado_se_03.pdf

International Criminal Court, Prosecutor v. Jean-Pierre Bemba Gombo (ICC-01/0501/08), Pre-Trial Chamber II, Decision Pursuant to Article 61(7)(a) and (b) of the Rome Statute, 15 June 2009. Disponible en: https://www.icc-cpi.int/car/bemba\#10, https://www.icc-cpi.int/Pages/record.aspx?docNo=ICC-01/05-01/08-424

International Criminal Tribunal for Rwanda, ICTR, Prosecutor v. Jean-Paul Akayesu (ICTR-96-4-T), Trial Chamber, Judgement, 2 September 1998. Disponible en: http://www.un.org/en/preventgenocide/rwanda/pdf/AKAYESU\%20-\%20JUDGEMENT.pdf

International Criminal Tribunal for Rwanda, ICTR, Prosecutor v. Ignace Bagilishema (ICTR-95-1A-A), Appeals Chamber, Judgement, 3 July 2002. Disponible en: http:// unictr.unmict.org/en/cases/ictr-95-1a, http:/unictr.unmict.org/sites/unictr.org/files/ case-documents/ictr-95-1a/appeals-chamber-judgements/en/020703.pdf

International Criminal Tribunal for Rwanda, ICTR, Prosecutor v. François Karera (ICTR-01-74-T), Trial Chamber I, Judgement and Sentence, 7 December 2007. Disponible en: http://unictr.unmict.org/en/cases/ictr-01-74, http://unictr.unmict. org/sites/unictr.org/files/case-documents/ictr-01-74/trial-judgements/en/071207.pdf

International Criminal Tribunal for Rwanda, ICTR, Prosecutor v. André Ntagerura, 
Emmanuel Bagambiki and Samuel Imanishimwe (ICTR-99-46-A), Appeals Chamber, Judgement, 7 July 2006. Disponible en: http://hrlibrary.umn.edu/instree/ICTR/ IMANISHIMWE_ICTR-97-36/IMANISHIMWE_ICTR-99-46-T.pdf

International Criminal Tribunal for the former Yugoslavia, ICTY, Prosecutorv. Blaškić (IT-95-14-T), Trial Chamber, Judgement, 3 March 2000. Disponible en: http://www. icty.org/x/cases/blaskic/tjug/fr/bla-tj000303f.pdf, http://www.icty.org/x/cases/ blaskic/tjug/en/bla-tj000303e.pdf

International Criminal Tribunal for the former Yugoslavia, ICTY, Prosecutor v. Blaškić (IT-95-14-A), Appeals Chamber, Judgement, 29 July 2004. Disponible en: http:// www.icty.org/x/cases/blaskic/acjug/en/bla-aj040729e.pdf

International Criminal Tribunal for the former Yugoslavia, ICTY, Prosecutor v. Zejnil Delalić, Zdravko Mucić (Aka "Pavo"), Hazim Delić and Esad Landžo (Aka “Zenga”) ("Čelebići Case”) (IT-96-21-T), Trial Chamber, Judgement, 16 November 1998. Disponible en: http://www.icty.org/x/cases/mucic/tjug/en/981116_judg_en.pdf

International Criminal Tribunal for the former Yugoslavia, ICTY, Prosecutor v. Zejnil Delalić, Zdravko Mucić (Aka "Pavo"), Hazim Delić and Esad Landžo (Aka "Zenga") ("Čelebići Case") (IT-96-21-A), Appeals Chamber, Judgement, 20 February 2001. Disponible en: http://www.icty.org/x/cases/mucic/acjug/en/cel-aj010220.pdf

International Criminal Tribunal for the former Yugoslavia, ICTY, Prosecutor v. Enver Hadžihasanović and Amir Kubura (IT-01-47-T), Trial Chamber, Judgement, 15 March 2006. Disponible en: http://www.icty.org/case/hadzihasanovic_kubura/4, http://www.icty.org/x/cases/hadzihasanovic_kubura/tjug/en/had-judg060315e.pdf

International Criminal Tribunal for the former Yugoslavia, ICTY, Prosecutor v. Enver Hadžihasanović, Mehmed Alagić and Amir Kubura (IT-01-47-AR72), Appeals Chamber, Decision on Interlocutory Appeal Challenging Jurisdiction in Relation to Command Responsibility, 16 July 2003. Disponible en: http://www.icty.org/case/ hadzihasanovic_kubura/4, http://www.icty.org/x/cases/hadzihasanovic_kubura/ acdec/en/030716.htm

International Criminal Tribunal for the former Yugoslavia, ICTY, Prosecutor v. Sefer Halilović (IT-01-48-T), Trial Chamber I, Judgement, 16 November 2005. Disponible en: http://www.icty.org/case/halilovic/4, http://www.icty.org/x/cases/halilovic/tjug/ en/tcj051116e.pdf

International Criminal Tribunal for the former Yugoslavia, ICTY, Prosecutor v. Dario Kordić and Mario Čerkez (IT-95-14/2-T), Trial Chamber, Judgment, 26 February 2001. Disponible en: http://www.icty.org/case/kordic_cerkez/4, http://www.icty. org/x/cases/kordic_cerkez/tjug/en/kor-tj010226e.pdf

International Criminal Tribunal for the former Yugoslavia, ICTY, Prosecutor v. $\mathrm{Na}$ ser Orić (IT-03-68-T), Trial Chamber II, Judgement, 30 June 2006. Disponible en: http://www.icty.org/case/oric/4, http://www.icty.org/x/cases/oric/tjug/en/orijud060630e.pdf 


\section{Jurisprudencia Extranjera}

United States Military Tribunal Nuremberg, United States of America v. Wilhelm von Leeb et al. [High Command Trial or OKW-Prozess], Judgment of 27 October 1948. Disponible en: http://werle.rewi.hu-berlin.de/High\%20Command\%20Case.pdf

United States Military Tribunal, Nuremberg, Hostage Case [Hostage Trial or GeiselProzess], Judgment of 19 February 1948. Disponible en: http://werle.rewi.hu-berlin. de/Hostage\%20Case090901mit\%20deckblatt.pdf

United States Supreme Court, In re Yamashita 327 U.S. 1 (1946). Disponible en: https:// supreme.justia.com/cases/federal/us/327/1/case.html

\section{Jurisprudencia colombiana}

Corte Constitucional, Sentencia C-574-92, 28 de octubre de 1992, magistrado ponente Ciro Angarita-Barón. Disponible en: http://corteconstitucional.gov.co/ relatoria/1992/C-574-92.htm

Corte Constitucional, Sentencia C-225-95, 18 de mayo de 1995, magistrado ponente Alejandro Martínez-Caballero. Disponible en: http://corteconstitucional.gov.co/ relatoria/1995/c-225-95.htm

Corte Constitucional, Sentencia C-358-97, 5 de agosto de 1997, magistrado ponente Eduardo Cifuentes-Muñoz. Disponible en: http://corteconstitucional.gov.co/ relatoria/1997/c-358-97.htm

Corte Constitucional, Sentencia C-878-00, 12 de julio de 2000, magistrado ponente Alfredo Beltrán-Sierra. Disponible en: http:/corteconstitucional.gov.co/ relatoria/2000/c-878-00.htm

Corte Constitucional, Sentencia C-579-13, 28 de agosto de 2013, magistrado ponente Jorge Ignacio Pretelt-Chaljub. Disponible en: http://corteconstitucional.gov.co/ relatoria/2013/c-579-13.htm

Corte Constitucional, Sentencia C-740-13, 23 de octubre de 2013, magistrado ponente Nilson Pinilla-Pinilla. Disponible en: http://corteconstitucional.gov.co/ relatoria/2013/c-740-13.htm

Corte Constitucional, Sentencia C-388-14, 25 de junio de 2014, magistrado ponente Luis Guillermo Guerrero-Pérez. Disponible en: http://corteconstitucional.gov.co/ relatoria/2014/c-388-14.htm

Corte Constitucional, Sentencia C-084-16, 24 de febrero de 2016, magistrado ponente Luis Ernesto Vargas-Silva. Disponible en: http://corteconstitucional.gov.co/ relatoria/2016/c-084-16.htm

Corte Constitucional, Sentencia SU1184-01, 13 de noviembre de 2001, magistrado ponente Eduardo Montealegre-Lynett. Disponible en: http://corteconstitucional. gov.co/relatoria/2001/su1184-01.htm

Corte Constitucional, Sentencia T-327-04, 15 de abril de 2004, magistrado ponente Alfredo Beltrán-Sierra. Disponible en: http://corteconstitucional.gov.co/ relatoria/2004/t-327-04.htm 
Corte Suprema de Justicia, Sala de Casación Penal, Radicación 35113, sentencia de casación, 5 de junio de 2014, magistrado ponente Eugenio Fernández-Carlier. Disponible en: http://190.24.134.101/corte/wp-content/uploads/relatorias/pe/b2jun2014/ SP7135-2014(35113).doc

Corte Suprema de Justicia, Sala de Casación Penal, Proceso 28017, sentencia de casación, 14 de noviembre de 2007, magistrado ponente Jorge Enrique Socha-Salamanca.

Corte Suprema de Justicia, Proceso 25536, sentencia de segunda instancia, 27 de julio de 2006, magistrado ponente Álvaro Orlando Pérez-Pinzón.

Corte Suprema de Justicia, Sala de Casación Penal, Proceso 24448, sentencia de casación, 12 de septiembre de 2007, magistrado ponente Augusto Ibáñez-Guzmán. FECHA?

Tribunal Superior de Distrito Judicial de Bogotá, Sala Penal, sentencia del 30 de enero de 2012 (Radicación: 110010704003200800025 09). Disponible en: http://www. procuraduria.gov.co/relatoria/media/file/flas_juridico/242_TSB-SP-EXP2012N00025-09.pdf

\section{Otros documentos}

Acuerdo sobre las Víctimas del Conflicto (borrador conjunto), "Sistema Integral de Verdad, Justicia, Reparación y No Repetición”, incluyendo la Jurisdicción Especial para la Paz; y Compromiso sobre Derechos Humanos, Comunicado Conjunto 64, La Habana, 15 de diciembre de 2015. Disponible en: http://equipopazgobierno. presidencia.gov.co/prensa/Paginas/acuerdo-sobre-las-victimas-del-conflicto.aspx

Acuerdo final para la terminación del conflicto y la construcción de una paz estable y duradera, 28 de agosto de 2016. Disponible en: https://www.mesadeconversaciones. com.co/sites/default/files/24_08_2016acuerdofinalfinalfinal-1472094587.pdf

Acuerdo final para la terminación del conflicto y la construcción de una paz estable y duradera, La Habana, 12 de noviembre de 2016. Disponible en: https://www.mesadeconversaciones.com.co/sites/default/files/12-1479102292.11-1479102292.2016nu evoacuerdofinal-1479102292.pdf

Acuerdo final para la terminación del conflicto y la construcción de una paz estable y duradera, 24 de noviembre de 2016. Disponible en: https://www.mesadeconversaciones.com.co/

Comunicado Conjunto \# 7, Bogotá, Colombia, 24 de noviembre de 2016, p. 2 (numeral 7). Disponible en: https://www.mesadeconversaciones.com.co/documentos/ comunicados-conjuntos

Organización de Naciones Unidas, ONU, Comisión de Derecho Internacional, Yearbook of the International Law Commission, Vol. II, Part Two, Informe de la Comisión a la Asamblea General sobre la labor realizada en su 48 período de sesiones (1996). Disponible en: http://legal.un.org/ilc/publications/yearbooks/english/ ilc_1996_v2_p2.pdf

Riordan, Kevin, Command Responsibility, en UN Audiovisual Library of International Law (14 February 2012). Disponible en: http://webtv.un.org/news-features/ audiovisual-library-of-international-law-avl/watch/kevin-riordan-on-command- 
responsibility/2623243067001

United Nations War Crimes Commission, Law Reports of Trials of War Criminals, Volume IV (United Nations War Crimes Commission, London, 1948). Disponible en: https://www.loc.gov/rr/frd/Military_Law/pdf/Law-Reports_Vol-4.pdf

United Nations War Crimes Commission, Law Reports of Trials of War Criminals, Volume VIII (United Nations War Crimes Commission, London, 1949). Disponible en: https://www.loc.gov/rr/frd/Military_Law/pdf/Law-Reports_Vol-8.pdf

United Nations War Crimes Commission, Law Reports of Trials of War Criminals, Volume XII (United Nations War Crimes Commission, London, 1949). Disponible en: https://www.loc.gov/rr/frd/Military_Law/pdf/Law-Reports_Vol-12.pdf 